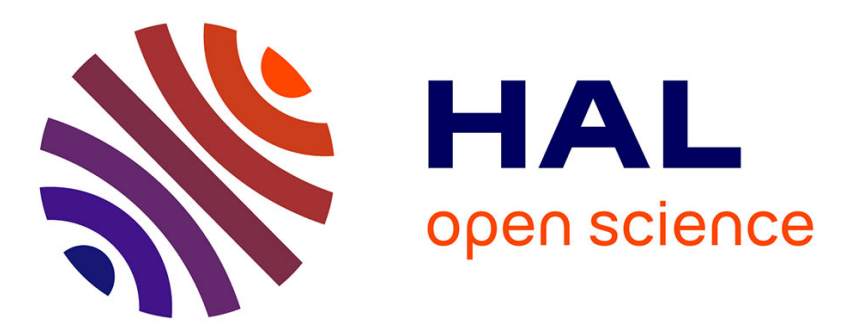

\title{
Characterization of fronts in the Western Mediterranean with a special focus on the North Balearic Front
}

\author{
Quentin-Boris Barral, Bruno Zakardjian, Franck Dumas, Pierre Garreau,
} Pierre Testor, Jonathan Beuvier

\section{- To cite this version:}

Quentin-Boris Barral, Bruno Zakardjian, Franck Dumas, Pierre Garreau, Pierre Testor, et al.. Characterization of fronts in the Western Mediterranean with a special focus on the North Balearic Front. Progress in Oceanography, 2021, 197, pp.102636. 10.1016/j.pocean.2021.102636 . hal-03298852

\section{HAL Id: hal-03298852 \\ https://hal.science/hal-03298852}

Submitted on 27 Jul 2021

HAL is a multi-disciplinary open access archive for the deposit and dissemination of scientific research documents, whether they are published or not. The documents may come from teaching and research institutions in France or abroad, or from public or private research centers.
L'archive ouverte pluridisciplinaire HAL, est destinée au dépôt et à la diffusion de documents scientifiques de niveau recherche, publiés ou non, émanant des établissements d'enseignement et de recherche français ou étrangers, des laboratoires publics ou privés. 


\section{Journal Pre-proofs}

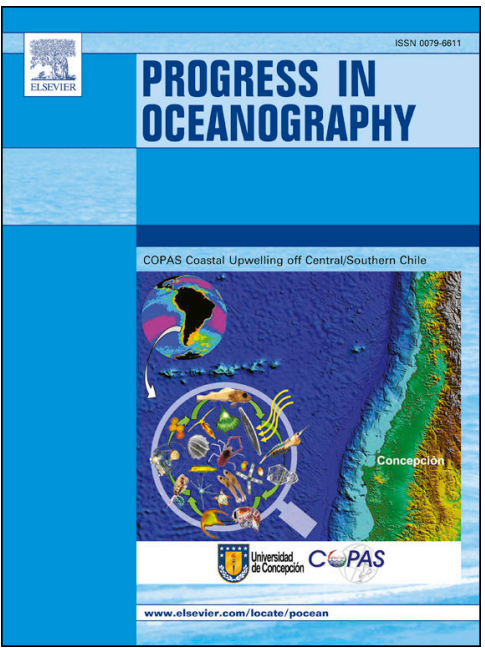

Characterization of fronts in the Western Mediterranean with a special focus on the North Balearic Front

Quentin-Boris Barral, Bruno Zakardjian, Franck Dumas, Pierre Garreau, Pierre Testor, Jonathan Beuvier

PII: S0079-6611(21)00121-X

DOI: https://doi.org/10.1016/j.pocean.2021.102636

Reference: PROOCE 102636

To appear in:

Progress in Oceanography

Received Date:

10 July 2020

Revised Date:

7 May 2021

Accepted Date:

24 June 2021

Please cite this article as: Barral, Q-B., Zakardjian, B., Dumas, F., Garreau, P., Testor, P., Beuvier, J., Characterization of fronts in the Western Mediterranean with a special focus on the North Balearic Front, Progress in Oceanography (2021), doi: https://doi.org/10.1016/j.pocean.2021.102636

This is a PDF file of an article that has undergone enhancements after acceptance, such as the addition of a cover page and metadata, and formatting for readability, but it is not yet the definitive version of record. This version will undergo additional copyediting, typesetting and review before it is published in its final form, but we are providing this version to give early visibility of the article. Please note that, during the production process, errors may be discovered which could affect the content, and all legal disclaimers that apply to the journal pertain.

(C) 2021 Published by Elsevier Ltd. 
Characterization of fronts in the Western Mediterranean with a special focus on the North Balearic Front

\author{
Quentin-Boris Barrala ${ }^{a}$ Bruno Zakardjian ${ }^{a}$, Franck Dumas ${ }^{b}$, Pierre Garreauc, Pierre Testor ${ }^{d}$, \\ Jonathan Beuviere \\ aUniv Toulon, Aix-Marseille Univ, CNRS/INSU, IRD, MIO UM 110, Mediterranean Institute of \\ Oceanography, La Garde, France \\ bSHOM, Service Hydrologique et Océanographique de la Marine, 13 rue de Chatelier, \\ CS592803, 29228 Brest CEDEX2, France \\ 'IFREMER, UNIV. Brest, CNRS UMR 6523, IRD, Laboratoire d'Océanographie Physique et \\ Spatiale (LOPS), IUEM, 29280 Plouzané, France \\ ${ }^{\mathrm{d}}$ CNRS-Sorbonne Universités (UPMC Univ. Pierre et Marie Curie, Paris 06)-CNRS-IRD- \\ MNHN, UMR 7159, Laboratoire d'Océanographie et de Climatologie (LOCEAN), Institut \\ Pierre Simon Laplace (IPSL), Observatoire Ecce Terra, Paris, France \\ eMercator Ocean International, Parc Technologique du Canal, 8-10 rue Hermès, 31520 \\ Ramonville Saint-Agne, France
}

\title{
Highlights
}

Thermal and haline fronts differ in the central part of the Algero-Provençal basin. Thermal fronts form a seasonal frontal zone from the Pyrenees almost toward Corsica. Salinity fronts form a quasi-permanent frontal zone from Mallorca to South Sardinia. The main salinity frontal zone shows a marked inter-annual variability. Deep Water Formation and Algerian Eddies spreading shift the haline front. Abstract

We focus on the characterization of thermohaline fronts in the Western Mediterranean, with a particular focus on the North Balearic Front (NBF), separating the Atlantic Waters that spread into the Algerian Basin from the saltier and colder waters of the Liguro-Provençal area. We use a simple gradient-based method of front detection applied to a 20-year (from June 1993 to June 2013) reanalysis of the Mediterranean. Statistics of daily frontal indices are used to identify areas of recurrent fronts, i.e., frontal zones. Comparisons with data from glider transects and remotely sensed sea surface temperature and altimetry data have been used to validate our approach from daily to seasonal and interannual time scales. Our method yielded two co-existing frontal zones in the area of the NBF. One with an almost permanent haline surface frontal zone extending southeastward from the Balearic Islands to Sardinia, representing the northern limit of the fresher Atlantic Water that spreads via instabilities of the Algerian Current and associated Algerian Eddies. Between years, its position shifts by about $1^{\circ}$ of latitude, possibly due to processes associated with both the deep water formation in the Provençal Basin and the spreading of southern Algerian Eddies. The second frontal zone is seasonal and thermally driven extending off the northeast of Menorca to the northwest of Corsica. The Pyrenees Front, a sharp thermal front off Cap de Creus which marks the boundary between the warm surface waters of the Balearic Sea and the cooler waters in the Gulf of Lion in late summer, appears to facilitate the formation of the aforementioned seasonal thermal front through the northeastward advection of its waters toward the West Corsican Current. The divergent eastward extensions of the two frontal zones, and their differences in nature, structure, and spatio-temporal variability, call for a revisit of the NBF appellation and a clarification of its dynamics.

\section{Keywords}


Frontal Detection; Seasonal Variability; Annual Variability; Deep Water Formation; Eddies; Western Mediterranean; North Balearic Front

Nomenclature
\begin{tabular}{|l|l|}
\hline Currents and eddies & Algerian Current \\
\hline AC & Balearic Current \\
\hline BC & Northern Current \\
\hline NC & West Corsican Current \\
\hline WCC & Algerian Eddy \\
\hline AE & \\
\hline Fronts & Balearic Front \\
\hline BF & North Balearic Front \\
\hline NBF & Pyrenees Front \\
\hline PF & \\
\hline Water masses & Atlantic Water \\
\hline AW & Levantine Intermediate Water \\
\hline LIW & modified Atlantic Water \\
\hline mAW & Western Mediterranean Deep Water \\
\hline WMDW & Deep Water Formation \\
\hline DWF & \\
\hline Other abbreviations & Frontal Indice \\
\hline FI & Frontal Occurrence \\
\hline FO & Gulf of Lion \\
\hline GoL & MEDiterranean ReanalYSis \\
\hline MEDRYS
\end{tabular}

\section{Introduction}

The Mediterranean Sea is a mid-latitude, semi-enclosed sea and a concentration basin where evaporation exceeds precipitation and run-offs due to a dry, windy, and relatively warm regional climate (Nof, 1979; Béthoux, 1980; Mariotti et al., 2002). The resulting salinity increases and water deficit are compensated by an anti-estuarine circulation through the Strait of Gibraltar that shows an inflow of Atlantic Water (AW) at the surface and an outflow of salty Mediterranean water at depth (Nof, 1979; Millot, 1987). The AW flows cyclonically around all Mediterranean sub-basins including the easternmost Levantine Basin and is continuously modified along its path by mixing with resident waters and marked air-sea exchanges. This leads to the notion of modified Atlantic Water (mAW) that will be used in this study to denote the older and saltier AW mainly present in the northern part of the Western Basin. In addition, wind forcing in autumn and winter causes intermediate to deep convection along nearly the entire northern Mediterranean coast, from the Gulf of Lion, over the Adriatic and Aegean Seas to the Levantine Basin, leading to the formation of several water masses and the establishment of a specific thermohaline circulation (Robinson and Golnaraghi, 1994; Bergamasco and MalanotteRizzoli, 2010; Waldman et al., 2018; Pinardi et al., 2019). This Mediterranean thermohaline circulation (MTHC) has a time scale of about 100 years, i.e., 10 times less than the THC in the global ocean, and was shown to have responded rapidly to climate variability during the last glacial period (Cacho et al., 2000). More recently, an abrupt shift in the intermediate part of the MTHC during the 1990s, the socalled Eastern Mediterranean Transient (EMT), has affected the water mass characteristics in both the eastern and western basins (Roether et al., 2007 for a thorough review of the EMT). All climate models, 
including IPCC-2007, predict an increase in the interannual rainfall variability in addition to strong warming and drying (Somot et al., 2008; de Sherbinin, 2014; Cramer et al., 2018) in the Mediterranean. Moreover, several recent studies have shown that the Mediterranean surface waters have been warming at $\sim 0.04^{\circ} \mathrm{C} . \mathrm{y}^{-1}$, i.e., four times the global rate over the last four decades, and that this trend affects both the surface, intermediate, and deep waters throughout the Mediterranean (Béthoux et al., 1998; VargasYáñez et al., 2008; Nykjaer, 2009; von Schuckmann et al., 2019; Pisano et al., 2020).

One of the main challenges to improve our current understanding of these dynamics in the Mediterranean is the wide range of scales of motion (from sub-meso to basin scale) that drive and regulate general circulation. The impact of sub-mesoscale $(1-10 \mathrm{~km})$ to mesoscale $(10-100 \mathrm{~km})$ variability on ocean circulation and associated water and heat fluxes is far from clear, neither at the global scale (Lévy et al., 2008, Griffies et al., 2014) nor at the basin scale for the Mediterranean (Millot, 1991; Robinson et al., 2001; Schroeder et al., 2011; Tintoré et al., 2019; Aguiar et al., 2020). In this (sub-) mesoscale range, oceanic fronts are ubiquitous features that separate water masses of different origins and, hence, different thermohaline characteristics (Fedorov, 1986). In the open ocean, they are often associated with regional geostrophic currents and are areas of increased vertical motions due to frontal or current instabilities that affect the productivity and fate of biomass (Pinot et al., 1995b; Lévy et al., 1998ab; Zakardjian and Prieur, 1998; Stemmann et al., 2008, Olita et al., 2014, as examples for the Mediterranean). Here, we will focus on the characterization and variability of thermohaline fronts in the Western Mediterranean and, more specifically, on the North Balearic Front (NBF) that is thought to separate the Liguro-Provençal and Algerian sub-basins (Fig. 1). Both sub-basins are characterized by marked differences in hydrology and dynamics. The regional circulation of the Liguro-Provençal subbasin is mainly governed by the Northern Current (NC), a major pathway of the mAW circulation in the northwestern Mediterranean (Millot, 1991), and sustained marked wind forcings (i.e., the Tramontane and Mistral winds) that generate intermittent but pronounced coastal upwellings and, above all, the formation of deep water during winter convection events (MEDOC GROUP, 1970; Schott et al., 1996; Millot 1999; Smith et al., 2008; Estournel et al., 2016b; Herrmann et al., 2017; Somot et al., 2016; Waldman et al., 2017ab, 2018; Testor et al., 2018). The Algerian sub-basin is dominated by the AW inflow through the Strait of Gibraltar which becomes the Algerian Current (AC) between the eastern end of the Alboran Sea and the Strait of Sicily. AC instabilities generate large $(\sim 100 \mathrm{~km})$ anticyclonic open sea eddies, called Algerian Eddies (AEs), that follow a cyclonic path and can cause some AW to accumulate in the southern sub-basin with residence times ranging from months to years (Millot et al., 1990; Millot, 1999; Puillat et al., 2002; Isern-Fontanet et al., 2003; Testor et al., 2005b; Escudier et al., 2016a; Garreau et al., 2018; Pessini et al., 2018, 2020). The boundary between these two dynamical systems is clearly visible on maps of averaged dynamic height (Rio et al., 2007) with associated geostrophic currents that suggest a near-closure of the mAW regional circulation between the Balearic Current (BC) toward the West Corsica Current (WCC). While numerical models generally reproduce this mAW cyclonic re-circulation over the northern sub-basin relatively well (Béranger et al., 2005, 2010; Beuvier et al., 2010, 2012), the few regional studies focusing on the NBF have not been able to demonstrate any barrier effect or zonal training of mAWs along the NBF (Schroeder et al., 2008). Thus, both the closing of the circulation of the saltier mAW over the northwestern sub-basin along the NBF and the supply of the WCC remain largely unexplained issues.

This dynamic and hydrological frontier is also apparent in remotely sensed chlorophyll-a concentrations and associated proxies of primary production, which show marked gradients between the northern and southern sub-basins, i.e., within the NBF area (Bosc et al., 2004; D'Ortenzio and Ribera d'Alcalà, 2009; Uitz et al., 2012; Mayot et al., 2016; Salgado-Hernanz et al., 2019). The higher productivity of the north-western sub-basin is traditionally explained by a more efficient replenishment of the surface layers with nutrients during winter convection, especially when compared to the waters of the southwestern sub-basin which contains more oligotrophic and highly stratified AW. Separating these two biological sub-systems, the NBF area has been characterized as an area of intermittent productivity in response to frontal instabilities (Uitz et al., 2012; Olita et al., 2014; Mayot et al., 2016), but with an important interannual component that has yet to be elucidated (Olita et al., 2011, Mayot et al., 2016). While increases in secondary production is routinely assessed in the Balearic, Ligurian, and Alboran fronts (Boucher et al., 1987; Thibault et al., 1994; Stemmann et al., 2002; Fernández de Puelles et al., 2003 , 2014), current knowledge on the biomass distributions or zooplankton diversity in the offshore 
NBF remains much more elusive (F. Carlotti, pers. com.), where a significantly increased secondary production can be deduced from a higher abundance of Bluefin tuna and cetaceans (Gannier and Praca, 2006; Fromentin et al., 2014).

These uncertainties regarding the possible role of the NBF in the regional circulation and biological productivity in the western Mediterranean, are mostly due to the high variability in surface conditions in the area of the suspected location of the NBF. The thermal front often exhibits meandering and eddy shedding on remotely sensed SST (Deschamps et al., 1984) and chlorophyll-A images (Olita et al., 2014). Several studies have shown that deep and intermediate eddies could cross the entire basin, e.g., as sub-mesoscale eddies consisting of Western Mediterranean Deep Water (WMDW) formed after convection events and spreading southeastward (Testor and Gascard 2003, Beuvier et al., 2012, Bosse et al., 2016) or of Levantine Intermediate Water (LIW) moving northwestward from Sardinia (Sardinian Eddy, SE; Testor et al., 2005b; Bosse et al., 2015). In contrast, vortex structures overlaying or interacting with the NBF are much less documented (Fuda et al., 2000, Pessini et al., 2018, Garreau et al., 2018) as are their interactions with the deep and intermediate ones. In addition, it has been shown that the NBF may rapidly shift by tens of kilometers under prevailing cross-front wind forcing (Estrada et al., 1999) and this horizontal displacement may be even more pronounced with strong northerly winds during Deep Water Formation (DWF) events (Estournel et al., 2016a).

Moreover, some ambiguities exist regarding the definition of the NBF in the literature. Early definitions used remote sensing data on sea surface temperature (SST) to identify the NBF as a thermal front northeast of the Balearic archipelago extending toward the north of Corsica (Deschamps et al., 1984). For Millot $(1987,1999)$, the NBF represented the northern edge of the AW reservoir in the Algerian Basin, while López-García et al. (1994) and Salat (1995) considered it as the eastward continuation of the Balearic Front (BF) toward Corsica, hence as the southern branch of the northwestern gyre of mAW re-circulation (see also Garreau et al., 2018; Seyfried et al., 2019). Estrada et al. (1999) defined the NBF as the northern edge of the Balearic Current, hence of the BF. Pascual et al. (2002) identified the BF (and consequently the NBF) based on AW-related salinity gradients, and distinguished it from the Pyrenees Front (PF) which marks the boundary between the warm surface waters of the Balearic Sea and the cooler waters in the Gulf of Lion in late summer. Most of these studies had a limited spatial coverage and focused mainly on the waters off the north and northeast of Menorca and the suggested eastward extension of the $\mathrm{NBF}$ toward $5^{\circ} \mathrm{E}$ only rests on the ordinary interpretation of the remotely sensed SST data.

The fuzzy definition of the NBF and the uncertainties regarding its possible role in the regional circulation of the western Mediterranean are finally due to the scarcity of dedicated observations in the NBF eddy-like complex area and the lack of objective criteria to define the front itself. The present study attempts to remedy this issue by providing a more precise characterization of the frontal interfaces associated with the NBF and their daily, seasonal, and pluri-annual variability. We used a simple but robust approach of normalized gradients to detect haline and thermal fronts in a high-resolution and long-term (20 y) reanalysis of the Mediterranean Sea (the MEDRYS reanalysis in Hamon et al. (2016) and Beuvier et al. (2016)). By using a reanalysis, i.e., a numerical model coupled with a multi-platform data assimilation system, allows to limit the potential bias and long-term tendencies often inherent in such hindcasts due to uncertainties in forcing and initial conditions and unresolved sub-grid processes (Balsameda et al., 2015). This approach makes it possible to construct the missing climatological statistics associated with the occurrences of temperature and salinity fronts, to characterize their main modes of variability, and identify the links with the main regional circulation patterns. This document is organized as follows. The in-situ, remotely sensed, and reanalysis data sets as well as the normalized gradient method are described in Section 2. In Section 3, we apply our method to detect temperature and salinity fronts in both modelled and observed data and evaluate their variability from the daily to the pluri-annual time scales. In Section 4, we discuss our method and the results, specifically the nature and variability of the most recurrent fronts in the NBF area, and we present our overall conclusion in section 5 . 


\section{Data and method}

\subsection{Modeling and observational datasets}

The present study uses data from the MEDRYS1V2 reanalysis that covers the period from October 1992 to June 2013 (Hamon et al., 2016; Beuvier et al., 2016). The reanalysis is based on the NEMOMED12 model (spatial resolution of $1 / 12^{\circ}$ or $\sim 7 \mathrm{~km}$ and $75 \mathrm{z}$ levels with higher vertical resolution near the surface) and the SAM2 assimilation scheme, as described in Lellouche et al., (2013) using satellite SST, altimetry, and in situ profiles of temperature and salinity (TS). The model was forced with ALDERA data, a downscaled version of the ERA-Interim reanalysis (Dee et al., 2011). The NOAA $0.25^{\circ}$ interpolated radiometry products (Reynolds et al., 2007) were used for the assimilation of SST at a resolution of $1^{\circ}$. The reanalysis also assimilates the AVISO along-track Sea Level Anomaly (SLA) product, by one every two points (to avoid taking into account redundant information) and without observations from within $50 \mathrm{~km}$ of the coasts. SLA data were then combined with the Mediterranean Mean Dynamic Topography (MDT) from Rio et al. (2011) to obtain ADT fields as the equivalent of the Sea Surface Height (SSH) of the model. TS profiles from the CORA4.1 database (Cabanes et al., 2013) were also assimilated, using only one profile per $0.1^{\circ}$ of latitude/longitude, day, and platform, and again omitting any observations from within $50 \mathrm{~km}$ of a coast.

We used L4 satellite SST observations from two different datasets of the Copernicus Marine Environment Monitoring Service (CMEMS): (1) a high resolution (HR, $1 / 25^{\circ}, \sim 4.5 \mathrm{~km}$, Pisano et al., 2016) dataset of daily averages stretching 35 years (1981-2017), used to calculate the long-term statistics for the occurrence of surface temperature fronts during the reanalysis period; (2) a very high resolution (VHR, $1 / 40^{\circ}, \sim 1.4 \mathrm{~km}$ ) dataset, ideally suited for front detection but with a limited temporal coverage of 2008-2017 (Buongiorno et al., 2013), used to validate the detection of daily surface thermal fronts from 2008 onwards (for years prior to 2008 the HR SST dataset was used). In order to be able to unambiguously compare the three datasets (i.e., the reanalysis and the two CMEMS SST data), the VHR SST data was spatially filtered (boxcar smoother) for space scales smaller than $7 \mathrm{~km}$.

Satellite-derived Sea Surface Salinity (SSS) data were not used in this study as the only available sources for such data, the Aquarius (SAC-D mission) and SMOS satellites, offer and insufficient spatial resolution for our purposes, of greater than $100 \mathrm{~km}$ and $\sim 30 \mathrm{~km}$, respectively (Lagerloef et al., 2008; Olmedo et al., 2018). SLA L4 altimetry data from AVISO/CMEMS for the period 1993-2017 (24 years) at $1 / 16^{\circ}(\sim 7 \mathrm{~km})$ spatial resolution were used to compare absolute dynamic topography (ADT) to MEDRYS simulated sea surface height (SSH).

Two glider datasets collected as part of the French CNRS/INSU program MISTRALS were used to test the ability of the reanalysis to conserve water mass distributions and associated gradients. Gliders move along saw-tooth-shaped trajectories oscillating between the surface and a maximum depth of $1000 \mathrm{~m}$, and capable of covering horizontal distances of $2-4 \mathrm{~km}$ in $2-4 \mathrm{~h}$ between two surfacings. They recorded temperature and salinity as well as biogeochemical properties at high temporal and spatial resolution which makes them particularly well-suited for observing fine-scale frontal features. The glider deployments were carried out during fall 2012 (glider CAMPE/MistralsT02_00 in the EGO database) and winter 2013 (glider MILOU/ASICSMED, EGO database). The gliders were equipped with pumped and unpumped CTD probes (SBE-41) that require offset correction as a first-order correction for each single deployment (see Bosse et al., 2016; Margirier et al., 2017; and Testor et al., 2018) and for the thermal lag issue of the CTD probe that can affect salinity measurements in strong thermoclines of the order of $0.1-1.0^{\circ} \mathrm{C} . \mathrm{m}^{-1}$ (Garau et al., 2011). To compare the glider data with our reanalysis we concatenated vertical profiles taken from the reanalysis using linear interpolation between the dates and geographical positions that correspond to the recorded surface positions of the glider dataset. Note that the glider data are used in the CORA4.1 database, but only for one profile per day, platform and $0.1^{\circ}$ of latitude/longitude. Thus, even if they are not strictly independent from the reanalyzed fields (being partially assimilated), we assume they can be used to verify that the reanalysis is well constrained by the observations, preserving the thermohaline characteristics of the water masses and associated gradients. 


\subsection{Detecting frontal interfaces and localizing frontal zones}

Fedorov (1986) introduced concepts and definitions that distinguish between frontal interfaces and frontal zones. A frontal interface (or front) is the surface outcrop of an isotherm and/or isohaline that marks the horizontal boundary between two water masses. The frontal zone (or front area) is the relatively stationary zone in time and space where the two water masses meet, hence where the front is frequently observed. The front and underlying stratified water mass structures may vary in time and space, jointly or individually, depending on the type of situation (i.e., open ocean vs. coastal or estuarine fronts) in response to wind forcing or local frontal dynamics. The spatial scale relevant for an offshore front roughly corresponds to the Rossby radius of deformation $(5-12 \mathrm{~km}$ in the Western Mediterranean, Escudier et al., 2016b) and is slightly less for a sub-mesoscale front. The frontal zone is rather dependent on the low-frequency regional dynamics causing the two water masses to meet. The spatial scale of a frontal zone is thus larger than the spatial scale of a front and should be relevant to regional gradients in thermohaline properties. Given these considerations, a front detection index can be defined as the area where the local gradient of thermohaline properties significantly exceeds the regional gradient. Based on numerous SST observations, Fedorov (1986) proposed an empirical ratio of 10 between the local and regional gradients to mark the presence of a frontal interface.

We used the same simple criterion to define a frontal index (FI) used on a daily basis to identify the location of surface front. Specifically, we first computed the norm of the local bi-dimensional spatial gradient, in order to account for oblique or curvilinear structures as :

$\nabla_{h} X=\sqrt{\left(\nabla_{l o n} X\right)^{2}+\left(\nabla_{l a t} X\right)^{2}}$

where X stands for temperature or salinity and both gradients have been estimated using centered discrete operators. These local gradients re then normalized using a climatological-mean gradient representative of the large scale distribution of the thermohaline properties over the Western Mediterranean :

$$
\nabla_{N} X=\left|\frac{\nabla_{h} X}{\nabla_{c l i m} X}\right|
$$

where is the climatological-mean large scale gradient (for temperature or salinity). Lastly, the frontal indices (FIs) were defined for each time step and model grid point as binary variables for a given threshold ratio, $\mathrm{R}_{\mathrm{t}}$ as follows :

if $\nabla_{N} X \geqslant R_{t} \Rightarrow F I=1$, else 0 (3)

This is a binary index of daily frontal interfaces that can be tagged, while its time average gives the spatial distribution of front occurrence (FO) in percent (\%) over the considered period (i.e., month, season, year, etc.), resulting in a map of frontal zones.

$F O=\frac{100}{N t} \sum_{1}^{N_{t}} F I(t)$ 
As the NBF represents the boundary between the southern and northern sub-basins of the Western Mediterranean, a natural choice for the climatological mean gradient is the mean latitudinal gradient of the long-term (20-year) averaged fields, while avoiding river fronts (mainly the Rhône and Ebro rivers) which give much stronger salinity gradients. These climatological temperature and salinity gradients are calculated as :

$\nabla_{\text {clim }}=\frac{1}{N_{\text {lon }} \cdot N_{\text {lat }}} \sum_{1}^{N_{\text {lon }}} \sum_{1}^{N_{\text {lat }}} \nabla_{\text {lat }}\left(\frac{1}{N_{t}} \sum_{1}^{N_{t}} X\right)$

where $\mathrm{X}$ is the field and $\mathrm{i}$ and $\mathrm{j}$ are the model grid points in both horizontal directions of the area bounded by $4.72^{\circ} \mathrm{E}$ to $7.65^{\circ} \mathrm{E}$ and from the Algerian coast in the south to $42.23^{\circ} \mathrm{N}$ (Fig. 2). In the top $60 \mathrm{~m}$ of the water column, these computations lead to climatological mean gradients of $5.0 \times 10^{-3}{ }^{\circ} \mathrm{C}^{-\mathrm{km}^{-1}}$ and $2.0 \times 10^{-3} \mathrm{~km}^{-1}$ for temperature and salinity, respectively. Below a depth of $60 \mathrm{~m}$, these gradients decrease rapidly by one order of magnitude down to $300 \mathrm{~m}$ (Fig. 2c and f). This marked decrease is consistent with the limited vertical extent of the AW in the south and, likewise, the oldest and saltier mAW in the north. A slight climatological latitudinal gradient, more marked for temperature, is noticeable in the depth range of the LIW $(300-800 \mathrm{~m})$, while the deepest layers are almost homogeneous. The corresponding longitudinal gradients (not shown) are 10 times weaker in the 0-300 m depth range and almost nonexistent at greater depths. We therefore assumed that these $0-60 \mathrm{~m}$ averaged latitudinal gradients are adequate representations of a regional gradient and can be used to scale the intensity of the temperature and salinity fronts.

As with any front detection method, the choice of the threshold ratio (Rt in Equation 3) used to identify frontal interfaces is pivotal. Fedorov (1986) primarily used continuous observations of temperature to establish the threshold ratio of 10 between the local and regional temperature gradients. He assessed the robustness of this value in different regions and for various dynamics systems. Running some preliminary tests on our dataset using $\mathrm{Rt}=10$ showed that the temperature-based FI yielded several spatially coherent (i.e., patterns that are continuous over several tens of kilometers) SST fronts (Fig. 3). When we applied the same threshold to salinity, the FI showed fronts mainly in the vicinity of the Rhône and Ebro river plumes, but only very few in the central part of the basin (compared to the temperaturebased FI) nor in the vicinity of the Balearic archipelago or along the Algerian Current where haline fronts are often observed. By using a lower value of $\mathrm{Rt}=5$ for the salinity data, the FI showed more coherent structures with shapes that were often similar to those obtained from the temperature-based FI, although their spatial extents did not always match perfectly (Fig. 4). This suggests that the Rt threshold should be adapted based on the spatial resolution of the dataset used, the hydrological characteristics of the region, and the variable itself. In fact, given the mean horizontal resolution used for the simulation (about $7 \mathrm{~km}$ ), the definition of the FIs in Equation 3 with $\mathrm{Rt}=10$ requires a temperature and salinity difference of $0.35^{\circ} \mathrm{C}$ or 0.14 , respectively, for a front to be detected across two adjacent grid cells. Using mean thermal expansion and haline contraction coefficients of $\alpha_{\mathrm{T}}=2.14 \times 10^{-4}$ $\mathrm{K}^{-1}$ and $\beta_{\mathrm{S}}=-7.6 \times 10^{-4} \mathrm{~kg} \cdot \mathrm{g}^{-1}$, respectively, and a reference density of $1028 \mathrm{~kg} \cdot \mathrm{m}^{-3}$, these temperature and salinity differences would imply absolute density differences of $0.077 \mathrm{~kg} \cdot \mathrm{m}^{-3}$ and $0.109 \mathrm{~kg} \cdot \mathrm{m}^{-3}$ for temperature and salinity, respectively. For both threshold ratios to be equivalent in terms of density difference between two adjacent grid cells, the threshold used for salinity would need to be about 7 , i.e., between our empirical value for salinity of 5 and Fedorov's value of 10 (for temperature). Furthermore, a front is never purely haline nor thermal (i.e., salinity and temperature gradients can act in the same or opposite directions) and the salinity gradients between the AW and mAW may be split across more than one frontal structure (e.g., between the $\mathrm{AC}$ and the $\mathrm{AE}$ or the $\mathrm{AE}$ and northern $\mathrm{mAW}$ ). We therefore used our empirical value of $\mathrm{Rt}=5$ for to calculate the salinity-based FIs and kept the original Fedorov value of $\mathrm{Rt}=10$ for temperature to estimate the long-term frontal occurrences. 


\section{Results}

\subsection{Daily surface fronts}

We first describe how the reanalysis simulates surface thermohaline fronts and assess the results by comparing them with remotely sensed SST fronts, ADT, and derived currents. As the assimilation improved as the reanalysis progressed in time (due to ARGO data becoming available after 2005), the particular examples in Figs. 3 and 4 were chosen to cover contrasting seasonal situations and the entire 20 -year reanalysis period. All these examples show that the reanalysis captured the patterns of observed surface temperature and dynamical topography at scales ranging from regional to mesoscale, with many smaller structures visible in the lower mesoscale range. This is particularly evident along the North African coast where the reanalysis always shows more marked mesoscale instabilities of the AC and associated AEs than the satellite-derived ADT. We must recall here that SST and dynamic height data are assimilated in the reanalysis with a reduced resolution: only every second SLA data point and only one data point per $1^{\circ}$ lat/lon for SST (see Section 2.1). Likewise, the ADT data used for the validation of the simulated SSH fields are of lower resolution $\left(1 / 8^{\circ}\right)$ and likely smoothed during the gridding process. A better resolution or increased mesoscale variability is precisely what would be expected from a reanalysis where the physics of the ocean model acts as a dynamic interpolator and is thus capable of generating its own realistic mesoscale variability.

Most of the detected salinity and temperature fronts are associated with these mesoscale structures. For the case of early winter, the temperature and salinity fronts show nearly continuous structures along the outer edges of the AC meanders, marking the boundary between the warmer AW that recently entered through the Strait of Gibraltar (salinities below 37) and colder waters in the AEs that have not yet been mixed with the saltier resident Mediterranean waters (salinity range 37-38). The observed SST field shows similar but less marked swirling of warmer AW in the AC meanders in the 25 January 1998 data (Fig. 3b-c), i.e., only few detected fronts. We presume that this results from the over-smoothing during the interpolation and merging of this medium-resolution $(5 \mathrm{~km}) \mathrm{SST}$ dataset.

The summer 2008 case is a contrasted situation in which the AC exhibits lower temperatures than the rest of the Algerian basin, particularly within an anticyclonic eddy near the outlet of the Alboran Sea $\left(0-1^{\circ} \mathrm{E}\right)$ and a marked offshore tongue of cold coastal waters around $2-4^{\circ} \mathrm{E}$. The latter may be due to either a wind-induced upwelling (Fig. 3e and f), an eddy-induced upwelling (Millot, 1979), a recent inflow of colder AW, or a combination of any of these factors. Similar patterns are detected in the remotely sensed SST and derived fronts but are less perceptible in the simulated salinity data. This summer case also shows seven AEs in the reanalysis (Fig. 4) with similar patterns (although sometimes partially merged) in the altimetry data. Temperature and salinity fronts both show marked structures wrapping around each of the four main eddies, many of them being visible on the observed SST derived fronts. The use of high-resolution remotely sensed SST helped to identify and validate many more SST fronts in this case compared to the winter of 1998, but it also revealed numerous scattered fronts' detection without any coherent spatial structures.

In autumn 2012, there are large AC meanders and two AEs : one at the outlet of the Alboran Sea and the second centered at $7^{\circ} \mathrm{E}-38^{\circ} \mathrm{N}$. The normalized temperature gradient, which delimits the northern edge of the $\mathrm{AC}$ meanders and eddies, is less clear than in the previous examples due to the lower temperature differences between the recent AW and the older and saltier waters in the AE area. In contrast, salinity and associated fronts are still clearly associated with the SSH mesoscale patterns. West (and East) of the Strait of Bonifacio, marked SST fronts seem to be associated with strong wind forcing (Fig. $3 \mathrm{i}$ and j).

In early March 2013, the situation is similar albeit more extreme in that the SST is colder and nearly homogeneous across the whole area, yielding only few identifiable coherent structures. Once again, the salinity-based detection yields more frontal structures and a better agreement with the observed mesoscale SSH patterns. The low number of temperature fronts for this last case is confirmed by the 
observed SST, at least in the central part of the Western Basin. The two large bands with no front detection in the western or eastern part of the basin suggest an over-smoothing of the interpolated temperature fields under cloudy conditions that had lasted for several days prior to the date shown. In most cases, normalized temperature and salinity gradients showed marked frontal structures at the entrance of the Tunisia-Sardinia channel, in agreement with the observed SST and SSH patterns. These thermohaline fronts mark the confluence of the AW with the Tyrrhenian older and saltier mAW that flows northwestward along the Sardinian coast or southwestward, depending on the strength and size of the AEs present in the area.

Another prominent regional pattern present in both the reanalysis and the remotely sensed SST is the colder core of the mAW in the northern part of the basin, extending from the southern part of the Gulf of Lion (GoL) to the central Ligurian Sea in summer and autumn. It extends further south to the Balearic Sea and along the coasts of Corsica and Sardinia in early and late winter. Several temperature frontal structures are detected on the edges of this regional pattern, especially when latitudinal differences in temperature are greatest (during summer and autumn). These features are essentially absent in the March 2013 data. On the northeastern edge of the cold core, temperature fronts are most often detected along the entire path of the Northern Current down to the GoL entrance, as well as along its two branches on either side of Corsica, i.e., the Eastern and Western Corsican currents. Over the GoL, both the observed and reanalyzed SSTs showed similar instabilities of the NC temperature front, likely due to interactions with wind-induced eddy shelf circulation (Petrenko et al., 2005) and frequent upwellings that fuel the cold core often present in the GoL and Ligurian Sea during summer (Millot and Wald, 1980). The July 2008 case represents a good example of one such wind-induced upwelling event, marked by colder waters spreading across a large part of the continental shelf and a southwestward entrainment of the Rhône river plume (Fig. 3 e-f-h). In summer and autumn, the southern edge of the cold core is marked by undulating and near-continuous thermal fronts extending from the Balearic archipelago to Corsica. These fronts are associated with coherent SSH patterns in the reanalysis, but not in the CMEMS-AVISO ADT fields whose spatial resolution appears too low to resolve such features lying in the lower range of the mesoscale. By contrast, the observed SST field shows similar structures, although not strictly spatially coincident, supporting the realism of the mesoscale variability of the reanalysis in this area. These thermal fronts correspond to the NBF as originally defined in Deschamps et al. (1984) and used in many other studies (Bosse et al., 2015; Waldman et al., 2017ab; Pessini et al., 2018). The sharp temperature front extending from the Catalan coast, south of Cap de Creus, toward Menorca is another recurrent feature in summer and autumn. It marks the southernmost extent of the Tramontane influence. It has been called the Pyrenees Front (PF) by Pascual et al. (2002) and separates surface mixed and cooled waters in the north from fully stratified waters in the south. The temperature fronts in the northern part of the Western Basin are less marked and often absent during early and late winter (prior to the formation of the seasonal thermocline) as seen in both the simulated and observed SST fields. In 2013, this area was marked by strong convections (Testor et al., 2018) resulting from atmospheric forcing and favorable oceanic conditions. This led to the formation of a large tongue of cold surface water extending from Balearic Sea to Corsica and Sardinia with SSTs below those observed in the middle of the basin.

In contrast, fewer salinity fronts were detected in the area influenced by the NC, along the southeastern edge of the cold core, and, more generally, in the whole northeastern sub-basin. This is due to low salinity gradients (approximately 0.2 on average) between the older, saltier mAW of the Tyrrhenian Sea and the cold cores present in the GoL and Ligurian Sea. Haline fronts are more prominent in the Balearic Sea, particularly during summer and autumn. These salinity fronts run northeastward from the Ibiza channel past the three Balearic Islands, as resulting from the frequent intrusions of recent AW into the channels of the archipelago. It corresponds to the Balearic Front (BF) as defined in López-García et al., 1994 and later by Pinot et al. (1995a), Pascual et al. (2002), Millot and Taupier-Letage (2005), and Ruiz et al. (2009). The fact that temperature and salinity fronts in the Balearic Sea are more marked and more frequent during summer and autumn could point toward a more complex eddy-driven circulation causing AW and mAW to mix (Pinot et al., 1994, 1995ab, 2002). 


\subsection{Vertical structures associated with the fronts}

In this section, we focus on the vertical thermohaline structures underlying the detected surface fronts, specifically on two specific time periods (late winter and late summer) for which glider data was available. The autumn deployment (Fig. 5) ran from September 17 to November 16, 2012 and consisted of two transects (glider's path shown Fig. 1). The first transect (Sept 17 - Nov 1) ran along an approximately northwest-to-southeast path from north of Cap de Creus $\left(3.5^{\circ} \mathrm{E}-42.5^{\circ} \mathrm{N}\right)$ to $39.6^{\circ} \mathrm{N}-6.6^{\circ} \mathrm{E}$ and back, passing by the LION moorings at $42.038^{\circ} \mathrm{N}-4.688^{\circ} \mathrm{E}$ near the expected center of the deep convection area (MEDOC GROUP, 1970; Testor et al., 2018). The second transect started on November 1 and consisted of a round-trip between the GoL shelf and the LION mooring. During the first transect, the glider encountered a marked thermohaline front at around $40.5^{\circ} \mathrm{N}$ separating the saltier $\mathrm{mAW}$ in the northwest $(\mathrm{S} \sim 38.3$ ) from the fresher AW (S 37.8) in the Southern Basin (Figs. 4). The glider crossed the front on the outgoing journey between September 28 and October 8 and again on its return journey between October 8 and October 18. The glider data showed that surface temperatures increased almost linearly from approximately $20^{\circ} \mathrm{C}$ to $25^{\circ} \mathrm{C}$ between the GoL shelf and the fresher $\mathrm{AW}$ core. Both surface temperature and salinity fronts were associated with subsurface thermohaline patterns that had a greater vertical extent for salinity $(0-200 \mathrm{~m})$ compared to temperature $(0-50 \mathrm{~m})$. The low salinity core extending to $200 \mathrm{~m}$ corresponds to the northern edge of the area influenced by AEs (Fig. 4). This AW core is warmer than the northern $\mathrm{mAW}$ with higher temperatures essentially limited to the upper mixed layer. The glider also crossed a low salinity vein over the GoL shelf slope (near Cap de Creus) that marks the location of the NC (several crossings between September 16-18, October 29 and November 2, and November 13-16). While the NC's salinity signature (38.1-38.2) extended to depths of about 200-250m, its thermal signature was almost undetectable, particularly after 25 October, due to seasonal cooling.

The second glider deployment covered a winter convection event and the following spring restratification (01/24/13 to 04/14/13). It consisted of several round-trips, always passing by the LION mooring station and one particular transect crossing the expected thermal NBF area and continuing southeastward to $40.14{ }^{\circ} \mathrm{N}$. As with the previous deployment, the glider crossed the NC several times: at the end of January off Toulon, February 5-7 (partial), February 15-18, March 29 - April 5, and again near the end of its deployment (Fig. 6). The average salinity in the NC was similar to the salinities measured during the previous deployment (around 38.2) and slightly lower (smaller than 38) in those parts of the NC that are close to the coast. During this deployment, the glider again found a frontal feature corresponding to the northern boundary of the AW (salinities lower than 37.8), this time with a slightly greater vertical extent $(300 \mathrm{~m})$ compared to the first deployment. Apart from the NC vein and fresher AW core, salinities and temperatures were nearly constant $\left(\sim 38.45\right.$ and $\left.\sim 13^{\circ} \mathrm{C}\right)$ prior to March 1 while the water column remained fully mixed (LIW core included) due to the formation of new WMDWs by deep convection (Houpert et al., 2016; Testor et al., 2018). The lowest observed temperatures were associated with low salinities (on February 15) and are likely due to dense shelf water sinking off Banyuls (France), although this water may not be sufficiently dense to sink all the way to the bottom (Estournel et al., 2016a). The confluence of these fully mixed waters and either the $\mathrm{NC}$ or the fresher AW core generate sharp salinity fronts that crop out at the surface. By mid-March, mesoscale processes again brought the mAW to the top of the water column which led to smoother but still marked surface salinity fronts. Due to the deep convection observed during this deployment, the temperature field was almost homogeneous before early March, showing only slightly higher temperatures in the LIW core, the NC and the fresher AW to the southeast from mid-March onward. This small temperature variability did not induce significant temperature surface fronts, except near the southern, fresher AW core. The higher temperatures toward the end of the deployment (after 5 April) were due to seasonal warming rather than a change in water mass.

Apart from some greater salinity anomalies during the first leg of the first deployment (September 19 to October 10), the virtual gliders both showed mesoscale patterns in the southern, fresher AW core and 
the NC that were consistent with observations, i.e., with similar horizontal and vertical extents as well as thermohaline properties and strength of the surface-associated fronts. Moreover, this consistency can also be observed at depth, particularly in the LIW core that appears in both the observations and the reanalysis with a spatio-temporal variability well phased with the upper $\mathrm{mAW}$ core, the NC vein and the deep mixing in the convection areas. The larger model/in-situ discrepancies during the first glider deployment were due to small-scale salinity anomalies at the base of the mixed layer and upper thermocline in the reanalysis. These anomalies extended toward the surface and generated small-scale salinity fronts not apparent in the glider data. The glider data did show several similar salinity anomalies at depths of around $40 \mathrm{~m}$, however, which affected the surface salinity gradients, e.g., in early October. We hypothesize these anomalies are likely due to uncorrected thermal lag which leads to sampling errors in the presence of strong temperature gradients and high vertical glider velocities. Although these glider records are usually corrected before adding them to the MISTRAL database (delayed time data), the near real time data that are added to the French and European Operational Oceanography (OO) systems are not. As the CORA database mainly relies on these OO systems, it is likely that the nearreal time uncorrected glider data were used in the reanalysis. Despite these small artefacts, the main salinity and temperature structures were well sampled and simulated, particularly the AW core and its edges which would correspond to the NBF.

\subsection{Climatological and seasonal surface frontal zones}

We now present the climatological means ( $20 \mathrm{y}$ ) of the computed temperature and salinity FIs in order to derive the corresponding FO index (Fig. 7) and then identify the frontal zones according to Fedorov. Setting aside the Ebro and Rhône river plumes that often show salinity FOs higher than $80 \%$, the temperature and salinity FOs over the whole area rarely exceed $50 \%$ due to the spatial and temporal variability of the mesoscale structures scattering and spreading out the fronts. Nevertheless, the climatological FOs revealed several areas with values between 25 and 50\% (most areas had values that were much lower). These frontal areas differ in their spatial extent and seasonality with regard to temperature and Salinity. Salinity FOs are much more marked in the southern part of the basin, including the Balearic Sea, and almost absent in its northeastern part. They are characterized by a large and almost continuous frontal zone (FOs around 30-50\%) extending from the Alboran Sea to the whole balearic islands, and then southeastward to the Tunisia-Sardinia channel. In the Balearic Sea, it clearly denotes the area of the BF. East of Menorca Island, the area with recurring frontal activity marks the northernmost edges of the AEs. The numerous frontal interfaces associated with eddies inside the Algerian Basin appearing on daily maps (e.g., Fig. 4) do not lead to significant frontal areas as they are randomly distributed in time and space, due to the high AE mesoscale variability. Similarly, strong variability of the Algerian Current prevents any significant spatial recurrence of frontal interfaces until the flow stabilizes in the Tunisia-Sicily channel. There, the salinity contrast between the eastward flowing AW and the saltier mAW of the Tyrrhenian Sea would again favor the recurrence of marked frontal interfaces and consequently reveal an important frontal zone.

The frequency of occurrence of surface salinity fronts appears to be similar between seasons with a weak seasonality (Fig. 7). This may be related to the low seasonal variability of AW inflow through the Strait of Gibraltar (AW inflow: $0.81 \pm 0.06 \mathrm{~Sv}$, annual amplitude of the seasonal cycle: $0.034 \pm 0.011 \mathrm{~Sv}$, see Soto-Navarro et al., 2010). Some seasonality exists locally, e.g., for the Rhone river plume front that remains on the shelf during autumn and winter (Fig. $7 \mathrm{~b}$ and e) and extends further south during spring and summer (Fig. 7c and d). The greater southward extension of the Rhône plume in spring is naturally due to higher rainfall and snowmelt while at other times its dynamics depends of different stratification and wind regimes generating different eddy retention patterns on the whole shelf (Estournel et al., 1997, 2003; Hu et al., 2011; Kersalé et al., 2013). Higher salinity FOs values (greater than 50\%) in the Tunisia-Sardinia channel in winter coincides with the winter increase in AC flow in the Tyrrhenian (Astraldi et al., 1999; Jebri et al., 2017) likely favoring more marked and less scattered FIs. The BF-related frontal zone is relatively constant between seasons, with FO values in the range of $30-40 \%$ most of the time, except in summer when values reach more than 50\% northwest of Mallorca. 
Near Menorca, FOs tend to be weaker and more spread out from winter until spring (Fig. 7b and d). A seasonal variability of the $\mathrm{BF}$ and $\mathrm{BC}$ has been attributed to the relative strength of the $\mathrm{mAW}$ flowing into the Balearic Sea with the NC acting against the AW northward intrusion through the Ibiza and Mallorca channels (López-García et al., 1994; Pinot et al., 2002; Mason and Pascual, 2013; VargasYáñez et al., 2020). The summer increase in the occurrence of salinity FOs northwest of Mallorca is consistent with the known spring to summer strengthening of the $\mathrm{BC}$ due to increased northward $\mathrm{AW}$ inflow across the Mallorca channel in combination with a summer weakening of the NC. The absence of a significant variability in the Ibiza and Mallorca channels, which would follow the same rule, is likely due to the insufficient spatial resolution of the reanalysis data. Given the width of the two channels (about $80 \mathrm{~km}$ each), the strong current shear that is observed between the northward and southward AW and mAW flows (e.g., Vargas-Yáñez et al., 2020) is barely visible in the ocean model which only shows a quasi-permanent but fuzzy confrontation of the AW and mAW in the southern Balearic Sea. The wintertime weakening of the salinity FO to the north and east of Menorca, which may represent the $\mathrm{NBF}$, suggests a larger mesoscale variability that would spread the daily frontal interfaces and weaken the corresponding FO. At the same time, FOs are significantly increased south of Menorca, suggesting a recurrent southward shift of the frontal zone in winter. This is likely related to the great variability of winter conditions in the northern basin, particularly considering the proximity of the area of WMDW formation. Conversely, the strengthening of the salinity frontal zone to the north and east of Menorca from spring to summer could be related to the strengthening of the $\mathrm{BC}$ that occurs at the same time or the northward shift of AEs in spring (Escudier et al., 2016a) or a combination of both. This will be discussed in more detail in Sections 4.3.

Temperature FOs show an almost opposite distribution compared to salinity FOs. Significant occurrences (FO greater than $25 \%$ ) are essentially limited to the northern part of the basin, i.e., the GoL and Ligurian Sea, and practically absent in the south except close to the coasts (Fig. 7f). Moreover, the temperature FOs exhibit a strong seasonal variability (likely due to seasonal surface cooling) with low values of $0-15 \%$ in winter increasing to $30 \%$ in spring and rising further to $30-60 \%$ in summer and early fall (the climatological average is $25-35 \%$ ). Being mostly found near the coasts, the higher FO values in summer and autumn are likely related to local wind forcing as over the eastern GoL due to frequent upwelling events (Millot, 1979; Millot and Wald, 1980; Stanev et al., 1989; Barrier et al., 2016) between Toulon and Marseille; near Cap de Creus in the area of the PF where the wind-cooled surface waters of the GoL meet the warmer waters of the Balearic Sea (López-García et al., 1994; Pascual et al., 2002; Mason and Pascual, 2013); east of the Strait of Bonifacio where western winds channeled by the strait (Fig. 3i) generate Ekman pumping and thus up- and downwellings (Marullo et al., 1994; Small et al., 2012); along the Algeria and Sardinia coasts as a result of coastal wind-induced upwellings in summer (Millot, 1990; Olita et al., 2013; Bosse et al., 2015) and eddy-induced upwellings at the Algerian coast (Millot, 1979).

Temperature FOs associated with major circulation patterns are less obvious, being either separated from the salinity ones or indistinguishable from the previously mentioned coastal and wind-related cases. The temperature FO signature of the AW is slightly more visible at the exit of the Alboran Sea, where values exceeding $25 \%$ are seen all along the African coast, although their narrow shape makes them essentially indistinguishable from coastal wind-induced FOs. Similar to the salinity derived FOs, the temperature FOs at the boundaries of the AEs in the AW reservoir are too variable in time and space to be able to produce significant and spatially coherent patterns on the long-term. While in winter temperature FOs show a slight increase (5-10\%) all along all along the northern edge of the AW reservoir, summer values do not, except northeast of Menorca Island, where a tongue of high FOs (more than $25 \%$ ) overlaps the northern part of the regional salinity frontal zone between $4^{\circ} \mathrm{E}$ and $6^{\circ} \mathrm{E}$. Nevertheless, it is unclear whether this tongue of high temperature FOs marks the northern limit of the AW or simply a southeastward extension of the PF. Moreover, it forms part of a larger area of similarly high FOs suggesting several temperature frontal interfaces throughout the GoL and Ligurian Sea during summer (Fig. 3), often following local upwelling events. This overlap between coastal and offshore features impedes the emergence of coherent structure along the NC that can only be clearly identified off the French Riviera (6- $\left.8^{\circ} \mathrm{E}\right)$ in the autumn average, with FO values greater than $25 \%$ in a coastal vein extending between the Ligurian Sea and the GoL. Despite marked FIs in summer and fall (Section 3.1), 
the thermal NBF extending toward Corsica (Deschamps et al., 1984) is not visible in the FOs, neither in the climatological not seasonal (summer/autumn) averages. In fact, both the satellite- and reanalysisderived temperature FOs show a large "hole" in the high-FO area $\left(7-8^{\circ} \mathrm{E}, 42-43^{\circ} \mathrm{N}\right)$ during summer. This may be due to a higher eddy-like variability preventing higher temperature FO values (akin to the argument regarding frontal interfaces in the southern sub-basin).

The marked seasonal variability of temperature FOs has been previously inferred from daily maps of FIs (Section 3.1) and is confirmed by the seasonal cycle of temperature FOs computed from the HR remotely sensed SST dataset (Fig. 7) which shows the same overall patterns although with much lower FO values (on average 15-20\% lower). These lower FO values in the HR SST dataset could be due to statistical effects related to interpolations on days with incomplete satellite coverage (e.g., cloudy days), i.e., the algorithms for optimal interpolation and merging used to produce daily gap-free maps may over-smooth in situ temperature gradients and spread them over large areas of missing pixels which in turn leads to poor or inefficient detection of temperature FIs. The VHR SST dataset generally gave much more temperature FIs (see Fig. 3), although the same over-smoothing issues may also affect the VHR dataset. For example, on March 32013 (Fig. 3o and p), there are two large bands without FI detection in the western and eastern parts of the basin, with several scattered temperature FIs detected in the central part of the basin (for both remotely sensed SST datasets). The fact that the $1 \mathrm{~km}$ remotely sensed dataset gave similar ranges and spatial patterns of FO as the reanalysis could serve as a confirmation of the over-smoothing bias in the HR SST dataset (Fig. 8). The only significant difference is the slightly higher background values of temperature FOs (5-10\%) when compared with the reanalysis over most of the low values southern area. These higher background values should be due to sub-mesoscale patterns (Stuhlmacher et al., 2020) that are not resolved in the reanalysis data, but as well to noisy pixels as many scattered and spatially incoherent temperature FIs can be seen on the VHR SST derived FI (Fig. 3). Nonetheless, these resolution and noise effects are smoothed-out in the longterm statistics and the good overall agreement between the reanalysis and the $1 \mathrm{~km}$ resolution SST dataset shows that the reanalysis generates realistic SST front occurrences.

\subsection{Interannual variability of frontal occurrence}

This section presents the interannual variability in the occurrence of temperature and salinity fronts. An empirical orthogonal function (EOF) analysis of the 20 -year daily FI fields yielded each first mode the first of temperature and the first of salinity - that explain $26.7 \%$ and $31.8 \%$ of variability respectively (Fig. 9), while higher modes had values of $2 \%$ and less in both cases (not shown). These first EOF spatial patterns are thus the most reliable modes of the FO variability while higher modes would account for intermittent and more randomly distributed patterns due to high frequency processes. The first thermal and haline modes mainly retain the same spatial patterns than the computed climatological FOs at the resolved space scales (Figs. 7 and 8). Moreover, the associated principal components confirmed the previous findings regarding the different modes of time variability for salinity and temperature FOs. The first principal component for temperature FI is clearly dominated by a seasonal variability with minima in winter and maxima in summer, consistent with the seasonal cycle shown Fig. 7. Furthermore, these extremes showed a low interannual variability. In contrast, the corresponding principal component for salinity FI did exhibit a marked interannual variability with higher values during the winters of 1998/99, 2002/03, 2003/04, 2008/09, and 2012/13 (Fig. 9d). Although the interpretation of EOF modes is always somewhat ambiguous, this first mode of time variability seems to be related to the intensity of the deep water formation events, as these winters correspond to years of deep convection in the MEDOC area (e.g., Somot et al., 2008; Herrmann et al., 2017; Waldman et al., 2017b).

The yearly frontal occurrences of temperature (Fig. 10) and salinity (Fig. 11) contain similar features as the 20-year climatology (Fig. 7). For temperature yearly FOs it includes higher FOs in the northern part (in the PF area and along the NC) and in areas of coastal upwellings (near Marseille, west of 
Sardinia, and along the Algerian coasts), and lower values in the southern part of the basin (the area influenced by AEs). Nevertheless, there is a significant interannual variability in the intensity and recurrence of thermal fronts. In 1995 there is a marked southeastward frontal zone that suggests a link with the AWs' northern limit (Fig. 11b). Areas with high FO values are also seen in the Ligurian Sea (1993, 2000-2001, 2003, 2005-2007, and 2009-2010). The offshore extent of the PF shows a different orientation in 2005-2007 and 2011-2012 (northeastward) compared to 2000 and 2004 (southeastward). Lastly, it appears that the background noise in the fronts shown in the Algerian Basin is slightly increased in 2004-2006 and 2009-2010 and lower in 2008, suggesting a significant interannual variability in either the AE activity or in the high frequency atmospheric forcing.

The interannual variability is much more evident in the salinity FOs (Fig. 11) which shows major changes in the intensity and position of the main haline frontal zone delineating AWs from mAWs between the Balearic Islands and Sardinia. The haline frontal zones related to the Rhône and Ebro river plume fronts are less variable between years. Only in 2000 there appears a slightly different location of the Rhône plume front reaching further south to $41^{\circ} \mathrm{N}$ and joining the AW/mAW haline front around 3$4^{\circ} \mathrm{E}$. In 2003, 2007-2008, and 2011-2012 the AW-mAW frontal zone was less well defined and even broke up at times. In other years known to have strong DWF, there was a southward shift of the AWmAW frontal zone to the east of Mallorca (1999, 2003-2005, and 2009-2010) affecting the whole BF zone in 2009-2010. Conversely, the northward shift of the southern BF limit from the Ibiza and Mallorca channel toward the Ebro delta in 1995 and 2002 suggests stronger AW intrusions into the Balearic Sea. In 1997, 1999, 2004, and especially in 2009 there was a northeastward extension of the haline frontal zone toward Corsica (matched by high SST FOs in 2004 only), suggesting a northeastward drive of AWs toward the WCC during these years. Moreover, the highest FO values occurred in 2004 in the central frontal zone. The years 1999 and 2003 show a net increase in salinity FO in the AE influenced area (southeast of the Balearic archipelago) which strongly contrasts with the low values seen in the climatological estimates (Fig. 7).

\section{Discussion}

\subsection{About the front detection method}

In this study, we choose to use the Fedorov (1986) gradient-based method for two reasons. First, it is a low computing-costs method given the numerous (7304) daily fields to be analyzed. Secondly, scaling the front intensity with the climatological gradients between the AW and mAW seemed best suited to capture temperature and salinity fronts relevant to the NBF. Nevertheless, when used with the $1 \mathrm{~km}$ resolution remotely sensed SST data, the gradient method also detected many scattered and noncoherent thermal fronts, highlighting a known weakness of such simple gradient approaches when used on high resolution and thus noisy data (Simpson, 1990). Many other front detection methods have been developed, particularly since the advent of ocean remote sensing. These methods employ various approaches, from simple gradient thresholds (Simpson, 1990; Moore et al., 1997; Kostianoy et al., 2004; Saraceno et al., 2004; Dong et al., 2006; Rivas and Pisoni, 2010), to mathematically more complex methods such as edge detection and classification (Cayula and Cornillon, 1992; Ullmann and Cornillon, 2000; Miller, 2009; Nieto et al., 2012), surface fitting and likelihood methods (Shaw and Vennel, 2000; Hopkins et al., 2010), or fractal-based methods of gradient discontinuities (Turiel et al., 2008; Yelekçi et al., 2017). Most of these methods focus on the detection of small-scale spatial patterns given the constraints of picture resolution, cloud cover and inherent experimental noise of remote sensed data. Numerical model results can be assumed noise-free as the scalar dynamics are usually well constrained by the physical core of the model. In such conditions, a gradient threshold method may be as efficient as edge detection methods (Simpson, 1990). Lastly, the scale of detectable frontal structures is restricted by the model's spatial resolution, about $6-7 \mathrm{~km}$ in our case, which means that the use of more sophisticated algorithms to track small scale fronts would not be of much use in our case. 
When using a gradient-based approach, the choice of the threshold used to to discriminate frontal pixels is clearly the more pivotal. Given the high seasonal variability of the SST fronts, the use of a constant threshold over the whole $20 \mathrm{y}$ of the reanalysis calls for some reservations. In fact, the mean latitudinal gradient of temperature varies seasonally from $4 \times 10^{-3}{ }^{\circ} \mathrm{C} \cdot \mathrm{km}^{-1}$ in winter to $7 \times 10^{-3}{ }^{\circ} \mathrm{C} \cdot \mathrm{km}^{-1}$ in autumn over the normalization domain, while the salinity one is less variable $\left(1.8 \times 10^{-3}\right.$ to $\left.2.2 \times 10^{-3} \mathrm{~km}^{-1}\right)$. This means that the temperature FOs should be slightly lower in winter and higher in autumn although seasonal values differ only slightly from the annual mean of $5 \times 10^{-3}{ }^{\circ} \mathrm{C} \cdot \mathrm{km}^{-1}$. Saraceno et al (2004) and Rivas and Pisoni (2010) used daily thresholds obtained from a cumulative histogram of the gradient norms for each daily SST image. This requires no a priori knowledge of regional gradients and allows to retain the short-term to seasonal variability of thermal fronts. We performed a comparison (not shown) between our threshold method and the histogram method of Rivas and Pisoni (2010). Both methods gave almost identical results with regard to daily FIs and long-term FOs. Indeed, we found that the histogram-based daily thresholds generally corresponded to ten and five times our climatological gradients for SST and SSS, respectively, and follow the same seasonal tendencies. This consistency between the two approaches confirms that the seasonal bias introduced by the use of timeconstant thresholds is not significant on a yearly basis and likely on a pluri-decadal one. Moreover, it supports the use of different thresholds for salinity and temperature gradients. It is more difficult to assess the ability of the front detection method for nearshore and on-shelf frontal structures, such as those linked to the Ebro and Rhône river plumes, coastal density-driven currents, or wind-induced coastal upwelling, as these phenomena would require the use of locally adjusted thresholds. The lack of SLA and TS profiles in coastal areas made the model less reliable than offshore and may cause an additional bias or drift. On the other hand, the well constrained offshore temperature and SSH fields would allow realistic forcing over the coastal area and the main limitation here is the spatial resolution of the reanalysis $\left(1 / 12^{\circ}\right)$ that does not allow to adequately resolve such coastal processes (Ourmières et al., 2011; Aznar et al., 2016). Nevertheless, we did not detect any significant discrepancies in coastal areas between the reanalysis and remotely sensed SST in the daily FI (Fig. 3) or their long-term occurrence (Fig. 8). This shows that most of the offshore mesoscale frontal interfaces in the Western Mediterranean can be scaled based on the climatological mean latitudinal gradients between AW and $\mathrm{mAW}$, at least to the first order or accuracy.

\subsection{The link between sea surface slope and salinity fronts}

AW, being fresher and generally warmer than other northern waters, are less dense and therefore raise the sea level in the Algerian sub-basin. At the same time, the continental winds prevailing over the northern part of the GoL continuously cool the older and saltier mAW, leading to a drop in SSH. The resulting mean difference in SSH is $20-25 \mathrm{~cm}$ over approximately $600 \mathrm{~km}$, even with the seasonal steric effect of warmed surface layers in summer. Based on this marked difference in sea level, Olita et al., (2011) used the largest ADT gradient between the northern and southern sub-basins as a marker of the $\mathrm{NBF}$, as the boundary between recent AW and saltier mAW. Fig. 12a shows that the average shape of the SSS frontal zone, extending from the north of Menorca Island to southwestern Sardinia, closely follows the highest mean SSH slope between the $-6 \mathrm{~cm}$ to $-2 \mathrm{~cm}$ isolines, hence in agreement with the Olita et al. (2011) hypothesis. Conversely, the temperature FOs do not show such a clear link with the dynamic topography, even in summer when the occurrence of thermal fronts is most frequent (Figs. 7 and 12b). One issue here is why the SST front between Menorca Island and Corsica, initially defined as the NBF in Deschamps et al. (1984), is neither evidenced in the long-term temperature FOs nor linked to the main SSH slope that marks the southern boundary of the northern mAWs (Seyfried et al., 2019). The potential contributions of temperature and salinity changes to density are however similar across the northern thermal front in summer/autumn $\left(\sim 3^{\circ} \mathrm{C}\right.$ in Fig. 3$)$ or across the BF and the main haline front ( $\sim 0.4$ on Fig. 4), leading to 0.66 and $0.70 \mathrm{~kg} . \mathrm{m}^{-3}$, respectively. But the mesoscale structures of the $\mathrm{AC}$ and AEs in the Algerian Basin to which the main salinity fronts are linked, are almost three times bigger (at least $150 \mathrm{~m}$ ) than the summer/autumn upper mixed layer thickness in the whole basin (about $50 \mathrm{~m}$, Figs. 5-6). This suggests a smaller scale geostrophic balance and lower contributions of temperature gradients to the main regional circulation patterns. 
In addition, many processes can trigger a high frequency variability of surface temperature fronts, such as wind induced spreading of surface fronts (Estrada et al., 1999; Capet et al., 2008b; Estournel et al., 2016a), mixed layer internal instabilities (Spall, 1995), or Ekman advection of buoyancy, causing either re- or de-stratification depending on whether the wind is aligned with the current or blows in the opposite direction (Turner, 1980; Fedorov and Ginsburg, 1988; Seyfried et al., 2017, 2019). Figs. 3-6 show that salinity and temperature surface fronts do not exactly coincide in space over the AW related mesoscale structures. Salinity fronts tend to occur on the external edges of the AC and AEs while temperature fronts appear more onshore for the current and swirl inside for the eddies. Indeed, summer temperature FOs computed just below the upper mixed layer depth $(30 \mathrm{~m})$ display patterns that are more consistent with the known thermal NBF signature, namely a thermal frontal zone extending further northeastward toward Corsica (Fig. 12b, white contours). It also shows a better continuity from the WCC to the Ligurian Sea and on to the GoL, as well as more recurrent patterns in the Balearic Sea. Conversely, the salinity FOs at depth are globally similar to the surface ones. This uncoupling of the surface thermal fronts from the underlying geostrophic structures has been described for the AlmériaOran front (Folkard et al., 1994). This suggests that most of the summer surface thermal fronts off western Corsica are due to turbulent structures in the upper mixed and warm layer rather than subsurface structures that would affect the dynamic height and geostrophic circulation. No equally strong temperature structure was detected in the main salinity frontal zone indicating that both fronts were of different origins.

\subsection{Interannual variability of the main central haline front}

Both the EOF and yearly analysis clearly showed that thermal frontal zones exhibited a low interannual variability and appeared to be driven rather by a seasonal cycle while salinity frontal zones were characterized by a stronger interannual variability. The fact that thermal fronts mainly showed a temporal variability on seasonal scales is likely due to the homogeneous winter cooling that reduces the surface temperature range in the entire Western Mediterranean (lower than $3^{\circ} \mathrm{C}$ compared to $6-8^{\circ} \mathrm{C}$ in summer/autumn, Figs. 3, 5, and 6). The higher thermal FOs seen in some years, particularly over the Ligurian Sea and GoL, may be primarily affected by the variability in summer/autumn wind and heat conditions. Conversely, Fig. 11 shows a $1-2^{\circ}$ latitudinal shift of the main haline frontal zone from year to year. Wind-induced shifts of fronts in the NBF area have been yet described by Estrada et al. (1999), Estournel et al. (2016a) and Seyfried et al. (2019), but on a short time scale (Fig. 12b, white) and not to such an extent. The principal component of the first EOF mode of salinity FI (Fig. 9b) suggested a link with the intensity of the DWF whose the southern extension can reach $40.5^{\circ} \mathrm{N}$ (Herrmann et al., 2010, 2017; Lebeaupin Brossier et al., 2017; Waldman et al., 2017a,b; Seyfried et al., 2019), close to the northern limit of the haline front. Moreover, the volume of new WMDW produced during a strong DWF winter can be as high as $50 \times 10^{3} \mathrm{~km}^{3}$, so one tenth of the total volume of the Northwestern Mediterranean (e.g., Somot et al. 2016). Such a large perturbation of the regional dynamics on a relatively short time scale (order of one month) is likely to have a pronounced effect of the AW/mAW spatial distribution, hence on the front's position.

Fig. 13 illustrates this likely effect by comparing daily salinity fields for a no/low convection year (2008) with a strong convection year (2005). While the AW and mAW are separated by a sharp haline front in both years, the latitudinal position of the main salinity front spans over more than $1^{\circ}$ interval between both cases. In winter 2005 there was a large area of fully mixed water column at $41-43^{\circ} \mathrm{N}$ marking the area of DWF (Figs. 13d and f). This structure was not present in March 2008 as no DWF occurred. The latitudinal shift of the main salinity front corresponds to half the diameter of the well mixed patch, suggesting that the formation of this process would have pushed the main salinity front southward. On the other hand, Fig. 13 also shows that the AW south of the front was clearly fresher in 2005 (lower than 37) compared to 2008 (higher than 37), suggesting a greater mixing of AW over the largest AEs affected area until 2008. A large interannual variability of the AEs' activity has been yet shown from eddy kinetic energy (EKE) estimates (Pujol and Larnicol 2005) or eddy tracking (Escudier 
et al. 2016a) with regular events of northward migration of long-lived AE up to $40^{\circ} \mathrm{N}$. This led us to consider the mean $\mathrm{AE}$ activity as another possible contributor to the interannual variability of the haline frontal zone.

Fig. 14 is an attempt to capture the relative contributions of AEs and DWF to the variability and strength of the main haline front over the whole $20 \mathrm{y}$ of the reanalysis. DWF is represented with the daily surface area of the convective zone defined as the area where the mixed layer depth exceeded $1000 \mathrm{~m}$ (Somot et al., 2008; Herrmann et al., 2017; Waldman et al., 2017b). Eddy activity is characterized by the EKE of the SSH-derived geostrophic current (Capó et al., 2019) yearly low-pass filtered to cover the typical $\mathrm{AE}$ and SE lifespans of months to years (Testor et al., 2005ab; Pessini et al., 2018). We defined the position of the haline front using the isohaline of 37.8 and 38.0, and used the normalized gradient (Equation 2) to measure the average strength of fronts. The results show that the mean (zonally averaged between 5 and $7^{\circ} \mathrm{E}$ ) latitudinal position of the front can vary by $2^{\circ}$ between 39.5 and $41.5^{\circ} \mathrm{N}$ with southward shifts following years of DWF (1999, 2003-2005 and 2009-2012) and northward return the following lower or no-convection years (2001-2002, 2006-2008). The intensity of the haline gradients most often coincides with the fresher isohaline (Fig. 14b). It is strongest at its northernmost and southernmost locations compared to times when the front shifts (e.g., 2008 or 2011). The northward shifts are often (but not always) associated with a northern extension of the high-EKE area (late 2000 and 2007), suggesting a northward relaxation of the AEs once they are no longer confined by the extent of the DWF area.

Nevertheless, it would remain highly speculative to resume this interannual variability of the main haline front position to the sole antagonistic effects of DWF vs the AEs northward spreading. Jevrejeva et al. (2006) and Iacono et al. (2013) observed a similar 6-y cycle in the SLA, which may be linked to shifts in the haline frontal zone (see Section 4.2 and Olita et al., 2011), but being rather due to an interannual variability of AW-mAW exchanges with the Tyrrhenian Sea. Likely, the geostrophic EKE may not result in the sole AEs and SEs activity. Mesoscale dynamics around the DWF area (Waldman et al., 2017a) and BC instabilities (Echevin et al., 2003; Bouffard et al., 2010) may produce EKE as well as small scale frontal eddies lying along the main haline front. We assume here that these processes do not contribute to the interannual variability of the front since their lifetime is of the order of weeks (Fuda et al., 2000; Pessini et al., 2018). Lastly, the strength of DWF depends on many factors among which the mean position of the NBF and the northward expansion of AW that may affect the DWF preconditioning by increasing water column buoyancy and reducing the surface available for convection (Madec et al., 1996; Grignon et al., 2010; Schroeder et al., 2010; Estournel et al., 2016a; Waldman et al., 2017a; Testor et al., 2018; Seyfried et al., 2017, 2019). The variability of the surface and intensity of DWF can then be a cause as well as a consequence of the latitudinal shifts of the haline front.

\section{Conclusions}

This study shows that using a simple gradient-based method allowed the detection of spatially coherent and realistic temperature and salinity frontal structures in a reanalysis of the Western Mediterranean. The comparisons with glider data and satellite-derived SST showed that most of the detected fronts were similar in shape and scales than those detected in simulated fields. Furthermore, the long-term statistics of frontal occurrences exhibited the same regional and seasonal patterns for remote sensed SST than for the reanalysis. The main result is that haline and thermal fronts differ either by their preferential locations or seasonal to interannual variability. Except the Rhône and Ebro plumes, salinity fronts are mainly found between the southern AW reservoir and the northern mAWs over a regionalscale area that extends throughout the Balearic Archipelago and southeastward to Sardinia. The resulting frontal zone well matches the dynamic topography patterns marking the northernmost extent of the area dominated by the AEs. This main haline frontal zone has a low seasonality, but a marked 
interannual variability that may be partly due to yearly changes in the winter DWF in the LiguroProvençal basin and the intensity of AEs' activity in the Algerian basin. In contrast, thermal fronts are more frequent in the northern part of the Western Mediterranean on the edges of the cold core of mAWs that lie from the GoL to the Ligurian Sea. This includes the NC, several coastal areas affected by windinduced upwellings and a likely offshore extension of the PF almost toward North Corsica. Those fronts are all characterized by a low interannual variability, but a marked seasonal cycle with lower occurrence in winter contrasting with high occurrence in summer/autumn. This seasonality is mainly due to the homogeneous winter cooling over the area that lower temperature gradients. One issue this study tried to resolve was the different definitions of the NBF that exist in the literature. Different dynamics and main modes of variability of thermal and haline frontal zones clearly call for a revisit of the NBF definition. First, regarding the Deschamps et al. (1984) definition of the NBF, it appears that the transition between the PF and the thermal front extending toward North Corsica is neither clear nor continuous, as those features are often affected by recurrent mesoscale instabilities. Moreover, its strong seasonality made it generally absent half of the year. Other definitions generally refer to the salinity gradient between the AWs from the Algerian sub-basin and the older mAWs of the Liguro-Provençal sub-basin. These two definitions cannot coexist as the thermal and haline fronts seldom coincide north of Menorca and are not driven by the same underlying dynamics. Moreover, the two frontal zones clearly diverge further to the east, as the haline frontal zone extends towards the south of Sardinia. Likewise, the NBF name itself assumes this front to be "northern" which is not compatible with the main southeastward orientation of the haline frontal zone east of the Balearic archipelago. Indeed, the NBF appellation would be restricted to the recurrent salinity front north of Menorca that marks the northernmost limit of the fresher AW from the Algerian basin. Possible alternative appellations for the eastern salinity and thermal fronts should better refer to their respective orientations, as for example the Balearic-Sardinia Frontal Zone and Pyrenees-Corsica Frontal Zone, respectively. The spatial divergence of the two frontal zones east of $6^{\circ} \mathrm{E}$ suggests that there is not a unique boundary between the northern Liguro-Provençal and southern Algerian sub-basins. Indeed, it reveals a large area, bounded by the two fronts and the Corsica and Sardinia coasts, which appears as a buffer zone from which the WCC is fueled. This buffer zone is also the area of SEs' formation and spreading whose eddy turbulence may favor AW/mAW mixing. How these dynamics interact remains unclear. This calls for more dedicated studies in this poorly known but likely critical area for the functioning of the Western Mediterranean, combining dedicated in situ campaigns with best eddy resolving modelizations or reanalysis.

\section{Acknowledgements}

This work was part of the PhD thesis of Q.-B. Barral funded by the French Ministère de l'Enseignement Supérieur, de la Recherche et de l'Innovation (MESRI). It is a contribution to the MISTRALS (Mediterranean INtegrated STudies at Regional And Local Scales) program through the CLOSCHEMED (CLOsure SCHEme of the MEDiterranean gyre) project funded by the French CNRS/INSU program LEFE-GMMC. Glider data were collected in the framework of the MISTRALS/Hymex and MOOSE (Mediterranean Ocean Observing System for the Environment, https://www.moose-network.fr/fr/) programs and made freely available by the EGO (Everyone's Gliding Observatories, https://www.ego-network.org/dokuwiki/doku.php). We would like to acknowledge the staff of the French National Pool of Gliders (DT-INSU/CNRS - CETSM/Ifremer) for the sustained glider deployments carried out in the framework of the above programs. This study has been conducted using E.U. Copernicus Marine Service Information. Remotely sensed sea level anomaly and sea surface temperatures came from CMEMS (Copernicus Marine Environment Monitoring Service, https://marine.copernicus.eu/).

- Product/Dataset:

Altimeter satellite gridded Sea Level Anomaly (SLA) (1993-Ongoing), E.U. Copernicus Marine Service Information product [Data set]. Available at: 
https://resources.marine.copernicus.eu/?option=com csw\&view=details\&product id=SEALE VEL_MED PHY_L4_REP_OBSERVATIONS 008 051 (Accessed: late 2017)

Mediterranean Sea - High Resolution L4 Sea Surface Temperature Reprocessed, E.U. Copernicus Marine Service Information product [Data set]. Available at:

https://resources.marine.copernicus.eu/?option $=$ com csw\&view=details\&product id=SEALE VEL MED PHY CLIMATE_L4_REP OBSERVATIONS 008056 (Accessed: late 2017)

Mediterranean Sea - High Resolution And Ultra High Resolution Sea Surface Temperature Analysis, E.U. Copernicus Marine Service Information product [Data set]. Available at:

https://resources.marine.copernicus.eu/?option $=$ com csw\&view=details\&product id $=$ SST_M ED_SST_L4_NRT_OBSERVATIONS 010 004 (Accessed: late 2017)

- Documentations :

G. Taburet and M.-I. Pujol, SL-TAC team (2020) CMEMS-SL-QUID-008-032-062, 4.2 edn., E.U. Copernicus Marine Service Information [Online]. Available at : https://resources.marine.copernicus.eu/documents/QUID/CMEMS-SL-QUID-008-032062.pdf (Accessed: late 2017)

Pisano, A., Buongiorno Nardelli, B., Tronconi, C., Santoleri, R., 2016. The new Mediterranean optimally interpolated pathfinder AVHRR SST Dataset (1982-2012). Remote Sens. Environ. 176, pp. 107-116. https://doi.org/10.1016/j.rse.2016.01.019

Buongiorno Nardelli, B., Tronconi, C., Pisano, A., Santoleri, R., 2013. High and Ultra-High resolution processing of satellite Sea Surface Temperature data over Southern European Seas in the framework of MyOcean project. Remote Sens. Environ. 129, pp. 1-16. https://doi.org/10.1016/j.rse.2012.10.012

\section{References}

Aguiar, E., Mourre, B., Juza, M., Reyes, E., Hernández-Lasheras, J., Cutolo, E., Mason, E., Tintoré, J., 2020. Multi-platform model assessment in the Western Mediterranean Sea: impact of downscaling on the surface circulation and mesoscale activity. Ocean Dynam. 70, pp. 273-288. Doi:

$\underline{10.1007 / \mathrm{s} 10236-019-01317-8}$

Astraldi, M., Balopoulos, S., Candela, J., Font, J., Gacic, M., Gasparini, G.P., Manca, B., Theocharis, A., Tintoré, J., 1999. The role of straits and channels in understanding the characteristics of Mediterranean circulation. Prog. Oceanogr. 44(1-3), pp. 65-108. Doi: 10.1016/S00796611(99)00021-X

Aznar, R., Sotillo, M.G., Cailleau, S., Lorente, P., Levier, B., Amo-Baladrón, A., Reffray, G., Álvarez-Fanjul, E., 2016. Strengths and weaknesses of the CMEMS forecasted and reanalyzed solutions for the Iberia-Biscay-Ireland (IBI) waters. Journal of Marine Systems 159, 1-14. Doi: 10.1016/j.jmarsys.2016.02.007

Balmaseda, M.A., Hernandez, F., Storto, A., Palmer, M.D., Alves, O., Shi, L., Smith, G.C., Toyoda, T., Valdivieso, M., Barnier, B., Behringer, D., Boyer, T., Chang, Y.-S., Chepurin, G.A., Ferry, N., Forget, G., Fujii, Y., Good, S., Guinehut, S., Haines, K., Ishikawa, Y., Keeley, S., Köhl, A., Lee, T., Martin, M.J., Masina, S., Masuda, S., Meyssignac, B., Mogensen, K., Parent, L., Peterson, K.A., Tang, Y.M., Yin, Y., Vernieres, G., Wang, X., Waters, J., Wedd, R., Wang, O., Xue, Y., Chevallier, 
M., Lemieux, J.-F., Dupont, F., Kuragano, T., Kamachi, M., Awaji, T., Caltabiano, A., WilmerBecker, K., Gaillard, F., 2015. The Ocean Reanalyses Intercomparison Project (ORA-IP). Journal of Operational Oceanography 8, s80-s97. Doi: $\underline{10.1080 / 1755876 X .2015 .1022329}$

Barrier, N., Petrenko, A.A., Ourmières, Y., 2016. Strong intrusions of the Northern Mediterranean Current on the eastern Gulf of Lion: insights from in-situ observations and high resolution numerical modelling. Ocean Dynamics 66, 313-327. Doi: 10.1007/s10236-016-0921-7

Béranger, K., Drillet, Y., Houssais, M.N., Testor, P., Bourdallé-Badie, R., Alhammoud, B., Bozec, A., Mortier, L., Bouruet-Aubertot, P., Crépon, M., 2010. Impact of the spatial distribution of the atmospheric forcing on water mass formation in the Mediterranean Sea. J. Geophys. Res. 115, p. C12041. Doi: $10.1029 / 2009 J C 005648$

Béranger, K., Mortier, L., Crépon, M., 2005. Seasonal variability of water transport through the Straits of Gibraltar, Sicily and Corsica, derived from a high-resolution model of the Mediterranean circulation. Prog. Oceanogr. 66, pp. 341-364. Doi: 10.1016/j.pocean.2004.07.013

Bergamasco, A., Malanotte-Rizzoli, P., 2010. The circulation of the Mediterranean Sea: a historical review of experimental investigations. Advances in Oceanography and Limnology 1, pp. 11-28. Doi: $\underline{10.1080 / 19475721.2010 .491656}$

Béthoux, J., 1980. Mean water fluxes across sections in the mediterranean-sea, evaluated on the basis of water and salt budgets and of observed salinities. Oceanolog. Acta 3, pp. 79-88.

https://archimer.ifremer.fr/doc/00122/23298/21125.pdf

Béthoux, J.P., Gentili, B., Tailliez, D., 1998. Warming and freshwater budget change in the Mediterranean since the 1940s, their possible relation to the greenhouse effect. Geophys. Res. Lett. 25, pp. 1023-1026. Doi: 10.1029/98GL00724

Beuvier, J., Béranger, K., Lebeaupin Brossier, C., Somot, S., Sevault, F., Drillet, Y., Bourdallé-Badie, R., Ferry, N., Lyard, F., 2012. Spreading of the Western Mediterranean Deep Water after winter 2005: Time scales and deep cyclone transport. J. Geophys. Res. 117, p. C07022. Doi:

10.1029/2011JC007679

Beuvier, J., Hamon, M., Greiner, E., Drévillon, M., and Lellouche, J.M., 2016. New version of MEDRYS, a Mediterranean Sea reanalysis during 1992- 2013. Rapp. Comm. Int. Mer Medit. Vol.41, p.123, Proceedings of the 41 th CIESM Congress, Kiel, Germany, September 2016

Beuvier, J., Sevault, F., Herrmann, M., Kontoyiannis, H., Ludwig, W., Rixen, M., Stanev, E., Béranger, K., Somot, S., 2010. Modeling the Mediterranean Sea interannual variability during 19612000: Focus on the Eastern Mediterranean Transient. J. Geophys. Res. 115, p. C08017. Doi: $\underline{10.1029 / 2009 J C 005950}$

Bosc, E., Bricaud, A., Antoine, D., 2004. Seasonal and interannual variability in algal biomass and primary production in the Mediterranean Sea, as derived from 4 years of SeaWiFS observations. Global Biogeochem. Cycles 18. Doi: 10.1029/2003GB002034

Bosse, A., Testor, P., Houpert, L., Damien, P., Prieur, L., Hayes, D., Taillandier, V., Durrieu de Madron, X., D'Ortenzio, F., Coppola, L., Karstensen, J., Mortier, L., 2016. Scales and dynamics of Submesoscale Coherent Vortices formed by deep convection in the northwestern Mediterranean Sea. J. Geophys. Res. Oceans 121, pp. 7716-7742. Doi: 10.1002/2016JC012144

Bosse, A., Testor, P., Mortier, L., Prieur, L., Taillandier, V., D'Ortenzio, F., Coppola, L., 2015. Spreading of Levantine Intermediate Waters by submesoscale coherent vortices in the northwestern 
Mediterranean Sea as observed with gliders. J. Geophys. Res. Oceans 120, pp. 1599-1622. Doi: $\underline{10.1002 / 2014 J C 010263}$

Boucher, J., Ibanez, F., Prieur, L., 1987. Daily and seasonal variations in the spatial distribution of zooplankton populations in relation to the physical structure in the Ligurian Sea Front. J Mar Res 45, 133-173. Doi: $\underline{10.1357 / 002224087788400891}$

Bouffard, J., Pascual, A., Ruiz, S., Faugère, Y., Tintoré, J., 2010. Coastal and mesoscale dynamics characterization using altimetry and gliders: A case study in the Balearic Sea. J. Geophys. Res. 115, p. C10029. Doi: $\underline{10.1029 / 2009 J C 006087}$

Buongiorno Nardelli, B., Tronconi, C., Pisano, A., Santoleri, R., 2013. High and Ultra-High resolution processing of satellite Sea Surface Temperature data over Southern European Seas in the framework of MyOcean project. Remote Sens. Environ. 129, pp. 1-16. Doi: 10.1016/j.rse.2012.10.012

Cabanes, C., Grouazel, A., Schuckmann, K. von, Hamon, M., Turpin, V., Coatanoan, C., Paris, F., Guinehut, S., Boone, C., Ferry, N., Boyer Montégut, C. de, Carval, T., Reverdin, G., Pouliquen, S., Traon, P.Y.L., 2013. The CORA dataset: validation and diagnostics of in-situ ocean temperature and salinity measurements. Ocean Sci. 9, pp. 1-18. Doi: 10.5194/os-9-1-2013

Cacho, I., Grimalt, J.O., Sierro, F.J., Shackleton, N., Canals, M., 2000. Evidence for enhanced Mediterranean thermohaline circulation during rapid climatic coolings. Earth Planet. Sc. Lett. 183, pp. 417-429. Doi: $\underline{10.1016 / \mathrm{S} 0012-821 \mathrm{X}(00) 00296-\mathrm{X}}$

Capet, X., McWilliams, J.C., Molemaker, M.J., Shchepetkin, A.F., 2008b. Mesoscale to Submesoscale Transition in the California Current System. Part II: Frontal Processes. J. Phys. Oceanogr. 38, pp. 44-64. Doi: $\underline{10.1175 / 2007 J P O 3672.1}$

Capó, E., Orfila, A., Mason, E., Ruiz, S., 2019. Energy Conversion Routes in the Western Mediterranean Sea Estimated from Eddy-Mean Flow Interactions. J. Phys. Oceanogr. 49, pp. 247 267. Doi: $\underline{10.1175 / J P O-D-18-0036.1}$

Cayula, J.F., Cornillon, P., 1992. Edge Detection Algorithm for SST Images. J. Atmos. Oceanic Technol. 9, pp. 67-80. Doi: 10.1175/1520-0426(1992)009\%3C0067:EDAFSI\%3E2.0.CO;2

Cramer, W., Guiot, J., Fader, M., Garrabou, J., Gattuso, J.P., Iglesias, A., Lange, M.A., Lionello, P., Llasat, M.C., Paz, S., Peñuelas, J., Snoussi, M., Toreti, A., Tsimplis, M.N., Xoplaki, E., 2018. Climate change and interconnected risks to sustainable development in the Mediterranean. Nature Climate Change 8, pp. 972-980. Doi: 10.1038/s41558-018-0299-2

de Sherbinin, A., 2014. Climate change hotspots mapping: what have we learned? Climatic Change 123, pp. 23-37. Doi: 10.1007/s10584-013-0900-7

Dee, D.P., Uppala, S.M., Simmons, A.J., Berrisford, P., Poli, P., Kobayashi, S., Andrae, U., Balmaseda, M.A., Balsamo, G., Bauer, P., Bechtold, P., Beljaars, A.C.M., Berg, L. van de, Bidlot, J., Bormann, N., Delsol, C., Dragani, R., Fuentes, M., Geer, A.J., Haimberger, L., Healy, S.B., Hersbach, H., Hólm, E.V., Isaksen, L., Kållberg, P., Köhler, M., Matricardi, M., McNally, A.P., Monge-Sanz, B.M., Morcrette, J.J., Park, B.K., Peubey, C., Rosnay, P. de, Tavolato, C., Thépaut, J.N., Vitart, F., 2011. The ERA-Interim reanalysis: configuration and performance of the data assimilation system. Q. J. Roy. Meteor. Soc. 137, pp. 553-597. Doi: 10.1002/qj.828

Deschamps, P.Y., Frouin, R., Crépon, M., 1984. Sea surface temperatures of the coastal zones of France observed by the HCMM satellite. J. Geophys. Res. 89, p. 8123. Doi:

$\underline{10.1029 / \mathrm{JC} 089 \mathrm{iC} 05 \mathrm{p} 08123}$ 
D’Ortenzio, F., Ribera d'Alcalà, M., 2009. On the trophic regimes of the Mediterranean Sea: a satellite analysis. Biogeosciences 6, 139-148. Doi: 10.5194/bg-6-139-2009

Dong, S., Sprintall, J., Gille, S.T., 2006. Location of the Antarctic Polar Front from AMSR-E Satellite Sea Surface Temperature Measurements. J. Phys. Oceanogr. 36, pp. 2075-2089. Doi: $\underline{10.1175 / J P O 2973.1}$

Echevin, V., Crépon, M., Mortier, L., 2003. Simulation and analysis of the mesoscale circulation in the northwestern Mediterranean Sea. Ann. Geophys. 21, pp. 281-297. Doi: 10.5194/angeo-21-281$\underline{2003}$

Escudier, R., Mourre, B., Juza, M., Tintoré, J., 2016a. Subsurface circulation and mesoscale variability in the Algerian subbasin from altimeter-derived eddy trajectories. J. Geophys. Res. Oceans 121, pp. 6310-6322. Doi: 10.1002/2016JC011760

Escudier, R., Renault, L., Pascual, A., Brasseur, P., Chelton, D., Beuvier, J., 2016b. Eddy properties in the Western Mediterranean Sea from satellite altimetry and a numerical simulation. Journal of Geophysical Research: Oceans 121, 3990-4006. Doi: 10.1002/2015JC011371

Estournel, C., Kondrachoff, V., Marsaleix, P., Vehil, R., 1997. The plume of the Rhone: numerical simulation and remote sensing. Cont. Shelf Res. 17, pp. 899-924. Doi: 10.1016/S0278$\underline{4343(96) 00064-7}$

Estournel, C., Madron, X.D. de, Marsaleix, P., Auclair, F., Julliand, C., Vehil, R., 2003. Observation and modeling of the winter coastal oceanic circulation in the Gulf of Lion under wind conditions influenced by the continental orography (FETCH experiment). J. Geophy. Res. Oceans 108, p. 8059. Doi: $\underline{10.1029 / 2001 J C 000825}$

Estournel, C., Testor, P., Damien, P., D’Ortenzio, F., Marsaleix, P., Conan, P., Kessouri, F., Durrieu de Madron, X., Coppola, L., Lellouche, J., Belamari, S., Mortier, L., Ulses, C., Bouin, M., Prieur, L., 2016a. High resolution modeling of dense water formation in the north-western Mediterranean during winter 2012-2013: Processes and budget. J. Geophys. Res. Oceans 121, pp. 5367-5392. Doi: 10.1002/2016JC011935

Estournel, C., Testor, P., Taupier-Letage, I., Bouin, M.N., Coppola, L., Durand, P., Conan, P., Bosse, A., Brilouet, P.E., Beguery, L., Belamari, S., Béranger, K., Beuvier, J., Bourras, D., Canut, G., Doerenbecher, A., Durrieu de Madron, X., D’Ortenzio, F., Drobinski, P., Ducrocq, V., Fourrié, N., Giordani, H., Houpert, L., Labatut, L., Lebeaupin Brossier, C., Nuret, M., Prieur, L., Roussot, O., Seyfried, L., Somot, S., 2016b. HyMeX-SOP2: The Field Campaign Dedicated to Dense Water Formation in the Northwestern Mediterranean. Oceanog. 29, pp. 196-206. Doi: 10.5670/oceanog.2016.94

Estrada, M., 1999. Spatio-temporal variability of the winter phytoplankton distribution across the Catalan and North Balearic fronts (NW Mediterranean). J. Plankton Res. 21, pp. 1-20. Doi: 10.1093/plankt/21.1.1

Fedorov K.N., 1986. The Physical Nature and Structure of Oceanic Fronts. Springer-Verlag, New York.

Fedorov, K.N., Ginsburg, A.I., 1992. The Near-Surface Layer of the Ocean. VSP, Utrecht, Netherlands.

Fernández de Puelles, M.L., Macias, V., Vicente, L., Molinero, J.C., 2014. Seasonal spatial pattern and community structure of zooplankton in waters off the Baleares archipelago (Central Western Mediterranean). Journal of Marine Systems 138, 82-94. Doi: 10.1016/j.jmarsys.2014.01.001 
Fernández de Puelles, M.L., Pinot, J.-M., Valencia, J., 2003. Seasonal and interannual variability of zooplankton community in waters off Mallorca island (Balearic Sea, Western Mediterranean): 19941999. Oceanologica Acta 26, 673-686. Doi: 10.1016/j.oceact.2003.07.001

Folkard, A.M., Davies, P.A., Prieur, L., 1994. The surface temperature field and dynamical structure of the Almeria-Oran front from simultaneous shipboard and satellite data. J. Marine Syst., Processes and Fluxes in the Geostrophic Almeria-Oran Front 5, pp. 205-222. Doi: 10.1016/09247963(94)90047-7

Fromentin, J.-M., Bonhommeau, S., Arrizabalaga, H., Kell, L.T., 2014. The spectre of uncertainty in management of exploited fish stocks: The illustrative case of Atlantic bluefin tuna. Marine Policy 47, 8-14. Doi: 10.1016/j.marpol.2014.01.018

Fuda, J.L., Millot, C., Taupier-Letage, I., Send, U., Bocognano, J.M., 2000. XBT monitoring of a meridian section across the western Mediterranean Sea. Deep-Sea Res. Pt. I 47, pp. 2191-2218. Doi: 10.1016/S0967-0637(00)00018-2

Gannier, A., Praca, E., 2007. SST fronts and the summer sperm whale distribution in the north-west Mediterranean Sea. J. Mar. Biol. Ass. 87, 187-193. Doi: 10.1017/S0025315407054689

Garau, B., Ruiz, S., Zhang, W.G., Pascual, A., Heslop, E., Kerfoot, J., Tintoré, J., 2011. Thermal Lag Correction on Slocum CTD Glider Data. J. Atmos. Oceanic Technol. 28, pp. 1065-1071. Doi: 10.1175/JTECH-D-10-05030.1

Garreau, P., Dumas, F., Louazel, S., Stegner, A., Le Vu, B., 2018. High-Resolution Observations and Tracking of a Dual-Core Anticyclonic Eddy in the Algerian Basin. J. Geophys. Res. Oceans 123, pp. 9320-9339. Doi: $\underline{10.1029 / 2017 J C 013667}$

Griffies, S.M., Yin, J., Durack, P.J., Goddard, P., Bates, S.C., Behrens, E., Bentsen, M., Bi, D., Biastoch, A., Böning, C.W., Bozec, A., Chassignet, E., Danabasoglu, G., Danilov, S., Domingues, C.M., Drange, H., Farneti, R., Fernandez, E., Greatbatch, R.J., Holland, D.M., Ilicak, M., Large, W.G., Lorbacher, K., Lu, J., Marsland, S.J., Mishra, A., George Nurser, A.J., Salas y Mélia, D., Palter, J.B., Samuels, B.L., Schröter, J., Schwarzkopf, F.U., Sidorenko, D., Treguier, A.M., Tseng, Y., Tsujino, H., Uotila, P., Valcke, S., Voldoire, A., Wang, Q., Winton, M., Zhang, X., 2014. An assessment of global and regional sea level for years 1993-2007 in a suite of interannual CORE-II simulations. Ocean Model. 78, pp. 35-89. Doi: 10.1016/j.ocemod.2014.03.004

Grignon, L., Smeed, D.A., Bryden, H.L., Schroeder, K., 2010. Importance of the variability of hydrographic preconditioning for deep convection in the Gulf of Lion, NW Mediterranean. Ocean Sci. 6, pp. 573-586. Doi: 10.5194/os-6-573-2010

Hamon, M., Beuvier, J., Somot, S., Lellouche, J.M., Greiner, E., Jordà, G., Bouin, M.N., Arsouze, T., Béranger, K., Sevault, F., Dubois, C., Drevillon, M., Drillet, Y., 2016. Design and validation of MEDRYS, a Mediterranean Sea reanalysis over the period 1992-2013. Ocean Sci. 12, pp. 577-599. Doi: $\underline{10.5194 / \mathrm{os}-12-577-2016}$

Herrmann, M., Auger, P.A., Ulses, C., Estournel, C., 2017. Long-term monitoring of ocean deep convection using multi-sensors altimetry and ocean color satellite data. J. Geophys. Res. Oceans 122(2), pp. 1457-1475. Doi: 10.1002/2016JC011833

Herrmann, M., Sevault, F., Beuvier, J., Somot, S., 2010. What induced the exceptional 2005 convection event in the northwestern Mediterranean basin? Answers from a modeling study. J. Geophys. Res. Oceans 115. Doi: 10.1029/2010JC006162 
Hopkins, J., Challenor, P., Shaw, A.G.P., 2010. A New Statistical Modeling Approach to Ocean Front Detection from SST Satellite Images. J. Atmos. Oceanic Technol. 27, pp. 173-191. Doi: 10.1175/2009JTECHO684.1

Houpert, L., Durrieu de Madron, X., Testor, P., Bosse, A., D’Ortenzio, F., Bouin, M.N., Dausse, D., Le Goff, H., Kunesch, S., Labaste, M., Coppola, L., Mortier, L., Raimbault, P., 2016. Observations of open-ocean deep convection in the northwestern Mediterranean Sea: Seasonal and interannual variability of mixing and deep water masses for the 2007-2013 Period. J. Geophys. Res. Oceans 121, pp. 8139-8171. Doi: $\underline{10.1002 / 2016 J C 011857}$

Hu, Z.Y., Petrenko, A.A., Doglioli, A.M., Dekeyser, I., 2011. Study of a mesoscale anticyclonic eddy in the western part of the Gulf of Lion. J. Marine Syst. 88, 3-11. Doi: 10.1016/j.jmarsys.2011.02.008

Iacono, R., Napolitano, E., Marullo, S., Artale, V., Vetrano, A., 2013. Seasonal Variability of the Tyrrhenian Sea Surface Geostrophic Circulation as Assessed by Altimeter Data. Journal of Physical Oceanography 43, 1710-1732. Doi: 10.1175/JPO-D-12-0112.1

Isern-Fontanet, J., García-Ladona, E., Font, J., 2003. Identification of Marine Eddies from Altimetric Maps. J. Atmos. Oceanic Technol. 20, pp. 772-778. Doi: 10.1175/15200426(2003)20\%3C772:IOMEFA\%3E2.0.CO;2

Jebri, F., Birol, F., Zakardjian, B., Bouffard, J., Sammari, C., 2016. Exploiting coastal altimetry to improve the surface circulation scheme over the central Mediterranean Sea. J. Geophys. Res. Oceans 121, pp. 4888-4909. Doi: 10.1002/2016JC011961

Jevrejeva, S., Grinsted, A., Moore, J.C., Holgate, S., 2006. Nonlinear trends and multiyear cycles in sea level records. Journal of Geophysical Research: Oceans 111. Doi: 10.1029/2005JC003229

Kersalé, M., Petrenko, A.A., Doglioli, A.M., Dekeyser, I., Nencioli, F., 2013. Physical characteristics and dynamics of the coastal Latex09 Eddy derived from in situ data and numerical modeling. J. Geophys. Res. Oceans 118, 399-409. Doi: 10.1029/2012JC008229

Kostianoy, A.G., Ginzburg, A.I., Frankignoulle, M., Delille, B., 2004. Fronts in the Southern Indian Ocean as inferred from satellite sea surface temperature data. J. Marine Syst. 45, pp. 55-73. Doi: 10.1016/j.jmarsys.2003.09.004

Lagerloef, G., Colomb, F.R., Le Vine, D., Wentz, F., Yueh, S., Ruf, C., Lilly, J., Gunn, J., Chao, Y., Decharon, A., Feldman, G., Swift, C., 2008. The AQUARIUS/SAC-D Mission: Designed to meet the salinity remote-sensing challenge. Oceanography 21 , pp. 68-81.

https://www.jstor.org/stable/24860158

Lebeaupin Brossier, C., Léger, F., Giordani, H., Beuvier, J., Bouin, M., Ducrocq, V., Fourrié, N., 2017. Dense water formation in the north-western Mediterranean area during HyMeX-SOP2 in $1 / 36^{\circ}$ ocean simulations: Ocean-atmosphere coupling impact. J. Geophys. Res. Oceans 122, pp. 5749-5773. https://doi.org/10.1002/2016JC012526

Lellouche, J.M., Le Galloudec, O., Drévillon, M., Régnier, C., Greiner, E., Garric, G., Ferry, N., Desportes, C., Testut, C.E., Bricaud, C., Bourdallé-Badie, R., Tranchant, B., Benkiran, M., Drillet, Y., Daudin, A., De Nicola, C., 2013. Evaluation of global monitoring and forecasting systems at Mercator Océan. Ocean Sci. 9, pp. 57-81. https://doi.org/10.5194/os-9-57-2013

Lévy, M., 2008. The Modulation of Biological Production by Oceanic Mesoscale Turbulence, in: Weiss, J.B., Provenzale, A. (Eds.), Transport and Mixing in Geophysical Flows: Creators of Modern Physics, Lecture Notes in Physics. Springer, Berlin, Heidelberg, pp. 219-261.

https://doi.org/10.1007/978-3-540-75215-8 9 
Lévy, M., Mémery, L., André, J.M., 1998a. Simulation of primary production and export fluxes in the Northwestern Mediterranean Sea. J. Mar. Res. 56, pp. 197-238.

https://doi.org/10.1357/002224098321836163

Lévy, M., Mémery, L., Madec, G., 1998b. The onset of a bloom after deep winter convection in the northwestern Mediterranean sea: mesoscale process study with a primitive equation model. J. Marine Syst. 16, pp. 7-21. https://doi.org/10.1016/S0924-7963(97)00097-3

Lopez-Garcia, M.J.L., Millot, C., Font, J., García-Ladona, E., 1994. Surface circulation variability in the Balearic Basin. J. Geophys. Res. 99, p. 3285. https://doi.org/10.1029/93JC02114

Madec, G., Delecluse, P., Crépon, M., Lott, F., 1996. Large-Scale Preconditioning of Deep-Water Formation in the Northwestern Mediterranean Sea. J. Phys. Oceanogr. 26, pp. 1393-1408. https://doi.org/10.1175/1520-0485(1996)026\%3C1393:LSPODW\%3E2.0.CO;2

Margirier, F., Bosse, A., Testor, P., L’Hévéder, B., Mortier, L., Smeed, D., 2017. Characterization of Convective Plumes Associated With Oceanic Deep Convection in the Northwestern Mediterranean From High-Resolution In Situ Data Collected by Gliders. J. Geophys. Res. Oceans 122, pp. 9814 9826. https://doi.org/10.1002/2016JC012633

Mariotti, A., Struglia, M.V., Zeng, N., Lau, K.M., 2002. The Hydrological Cycle in the Mediterranean Region and Implications for the Water Budget of the Mediterranean Sea. J. Climate 15, pp. 1674 1690. https://doi.org/10.1175/1520-0442(2002)015\%3C1674:THCITM\%3E2.0.CO;2

Marullo, S., Santoleri, R., Bignami, F., 1994. The surface characteristics of the Tyrrhenian Sea: Historical satellite data analysis, in: La Viollette, P.E. (Ed.), Coastal and Estuarine Studies. American Geophysical Union, Washington, D. C., pp. 135-154.

Mason, E., Pascual, A., 2013. Multiscale variability in the Balearic Sea: An altimetric perspective: Balearic Sea Variability. J. Geophys. Res. Oceans 118, pp. 3007-3025. https://doi.org/10.1002/jgrc.20234

Mayot, N., D’Ortenzio, F., Ribera d'Alcalà, M., Lavigne, H., Claustre, H., 2016. Interannual variability of the Mediterranean trophic regimes from ocean color satellites. Biogeosciences 13, 1901-1917. https://doi.org/10.5194/bg-13-1901-2016

MEDOC GROUP, 1970. Observation of Formation of Deep Water in the Mediterranean Sea, 1969. Nature 227, pp. 1037-1040. https://doi.org/10.1038/2271037a0

Miller, P., 2009. Composite front maps for improved visibility of dynamic sea-surface features on cloudy SeaWiFS and AVHRR data. J. Marine Syst., Special Issue on Observational Studies of Oceanic Fronts 78, pp. 327-336. https://doi.org/10.1016/j.jmarsys.2008.11.019

Millot, C., 1979. Wind induced upwellings in the gulf of lions. Oceanolog. Acta 2, pp. 261-274. https://archimer.ifremer.fr/doc/00122/23335/

Millot, C., 1987. Circulation in the western mediterranean-sea. Oceanolog. Acta, 10(2), pp. 143-149. Open Access version : https://archimer.ifremer.fr/doc/00108/21915/

Millot, C., 1990. The Gulf of Lions' hydrodynamics. Cont. Shelf Res. 10, pp. 885-894. https://doi.org/10.1016/0278-4343(90)90065-T

Millot, C., 1991. Mesoscale and seasonal variabilities of the circulation in the western Mediterranean. Dynamics of Atmospheres and Oceans 15, pp. 179-214. https://doi.org/10.1016/0377$\underline{0265(91) 90020-\mathrm{G}}$ 
Millot, C., 1999. Circulation in the Western Mediterranean Sea. J. Marine Syst. 20, pp. 423-442. https://doi.org/10.1016/S0924-7963(98)00078-5

Millot, C., Taupier-Letage, I., 2005. Circulation in the Mediterranean Sea, in: Saliot, A. (Ed.), The Mediterranean Sea, Handbook of Environmental Chemistry. Springer, Berlin, Heidelberg, pp. 29-66. https://doi.org/10.1007/b107143

Millot, C., Taupier-Letage, I., Benzohra, M., 1990. The Algerian eddies. Earth-Science Reviews 27, pp. 203-219. https://doi.org/10.1016/0012-8252(90)90003-E

Millot, C., Wald, L., 1980. The effect of Mistral wind on the Ligurian current near Provence. Oceanolog. Acta 3, pp. 399-402. https://archimer.ifremer.fr/doc/00122/23282/21111.pdf

Moore, J.K., Abbott, M.R., Richman, J.G., 1997. Variability in the location of the Antarctic Polar Front $\left(90^{\circ}-20^{\circ} \mathrm{W}\right)$ from satellite sea surface temperature data. J. Geophys. Res. Oceans 102, pp. 27825-27833. https://doi.org/10.1029/97JC01705

Nieto, K., Demarcq, H., McClatchie, S., 2012. Mesoscale frontal structures in the Canary Upwelling System: New front and filament detection algorithms applied to spatial and temporal patterns. Remote Sens. Environ. 123, pp. 339-346. https://doi.org/10.1016/j.rse.2012.03.028

Nof, D., 1979. On man-induced variations in the circulation of the Mediterranean Sea. Tellus 31, pp. 558-564. https://doi.org/10.1111/j.2153-3490.1979.tb00937.x

Nykjaer, L., 2009. Mediterranean Sea surface warming 1985-2006. Clim. Res. 39, pp. 11-17. https://doi.org/10.3354/cr00794

Olita, A., Ribotti, A., Fazioli, L., Perilli, A., Sorgente, R., 2013. Surface circulation and upwelling in the Sardinia Sea: A numerical study. Cont. Shelf Res. 71, pp. 95-108.

https://doi.org/10.1016/j.csr.2013.10.011

Olita, A., Ribotti, A., Sorgente, R., Fazioli, L., Perilli, A., 2011. SLA-chlorophyll-a variability and covariability in the Algero-Provençal Basin (1997-2007) through combined use of EOF and wavelet analysis of satellite data. Ocean Dynam. 61, pp. 89-102. https://doi.org/10.1007/s10236-010-0344-9

Olita, A., Sparnocchia, S., Cusí, S., Fazioli, L., Sorgente, R., Tintoré, J., Ribotti, A., 2014.

Observations of a phytoplankton spring bloom onset triggered by a density front in NW

Mediterranean. Ocean Sci. 10, pp. 657-666. https://doi.org/10.5194/os-10-657-2014

Olmedo, E., Taupier-Letage, I., Turiel, A., Alvera-Azcárate, A., 2018. Improving SMOS Sea Surface Salinity in the Western Mediterranean Sea through Multivariate and Multifractal Analysis. Remote Sensing 10, p. 485. https://doi.org/10.3390/rs10030485

Ourmières, Y., Zakardjian, B., Béranger, K., Langlais, C., 2011. Assessment of a NEMO-based downscaling experiment for the North-Western Mediterranean region: Impacts on the Northern Current and comparison with ADCP data and altimetry products. Ocean Modelling 39, 386-404. https://doi.org/10.1016/j.ocemod.2011.06.002

Pascual, A., Nardelli, B.B., Larnicol, G., Emelianov, M., Gomis, D., 2002. A case of an intense anticyclonic eddy in the Balearic Sea (western Mediterranean). J. Geophys. Res. Oceans 107( C11), p. 3183. https://doi.org/10.1029/2001JC000913

Pessini, F., Cotroneo, Y., Olita, A., Sorgente, R., Ribotti, A., Jendersie, S., Perilli, A., 2020. Life history of an anticyclonic eddy in the Algerian basin from altimetry data, tracking algorithm and in situ observations. J. Marine Syst. 207, p. 103346. https://doi.org/10.1016/j.jmarsys.2020.103346 
Pessini, F., Olita, A., Cotroneo, Y., Perilli, A., 2018. Mesoscale eddies in the Algerian Basin: do they differ as a function of their formation site? Ocean Sci. 14, pp. 669-688. https://doi.org/10.5194/os-14669-2018

Petrenko, A., Leredde, Y., Marsaleix, P., 2005. Circulation in a stratified and wind-forced Gulf of Lions, NW Mediterranean Sea: in situ and modeling data. Cont. Shelf Res. 25, pp. 7-27. https://doi.org/10.1016/j.csr.2004.09.004

Pinardi, N., Cessi, P., Borile, F., Wolfe, C.L.P., 2019. The Mediterranean Sea Overturning Circulation. J. Phys. Oceanogr. 49, pp. 1699-1721. https://doi.org/10.1175/JPO-D-18-0254.1

Pinot, J.M., López-Jurado, J.L., Riera, M., 2002. The CANALES experiment (1996-1998). Interannual, seasonal, and mesoscale variability of the circulation in the Balearic Channels. Prog. Oceanogr. 55, pp. 335-370. https://doi.org/10.1016/S0079-6611(02)00139-8

Pinot, J.M., Tintoré, J., Gomis, D., 1994. Quasi-synoptic mesoscale variability in the Balearic Sea. Deep-Sea Res. Pt. I 41, pp. 897-914. https://doi.org/10.1016/0967-0637(94)90082-5

Pinot, J.M., Tintoré, J., Gomis, D., 1995. Multivariate analysis of the surface circulation in the Balearic Sea. Prog. Oceanogr. 36, pp. 343-376. https://doi.org/10.1016/0079-6611(96)00003-1

Pinot J.M., Tintoré J, López-Jurado J.L., Fernandez des Puelles M.L., Jansa J (1995). Threedimensional circulation of a mesoscale eddy/front system and its biological implications. Oceanologica Acta, 18(4), pp. 389-400. Open Access version : https://archimer.ifremer.fr/doc/00097/20787/

Pisano, A., Buongiorno Nardelli, B., Tronconi, C., Santoleri, R., 2016. The new Mediterranean optimally interpolated pathfinder AVHRR SST Dataset (1982-2012). Remote Sens. Environ. 176, pp. 107-116. https://doi.org/10.1016/j.rse.2016.01.019

Pisano, A., Marullo, S., Artale, V., Falcini, F., Yang, C., Leonelli, F.E., Santoleri, R., Buongiorno Nardelli, B., 2020. New Evidence of Mediterranean Climate Change and Variability from Sea Surface Temperature Observations. Remote Sensing 12, 132. https://doi.org/10.3390/rs12010132

Puillat, I., Taupier-Letage, I., Millot, C., 2002. Algerian Eddies lifetime can near 3 years. J. Marine Syst. 31, pp. 245-259. https://doi.org/10.1016/S0924-7963(01)00056-2

Pujol, M.I., Larnicol, G., 2005. Mediterranean sea eddy kinetic energy variability from 11 years of altimetric data. J. Marine Syst. 58, pp. 121-142. https://doi.org/10.1016/j.jmarsys.2005.07.005

Reynolds, R.W., Smith, T.M., Liu, C., Chelton, D.B., Casey, K.S., Schlax, M.G., 2007. Daily HighResolution-Blended Analyses for Sea Surface Temperature. J. Climate 20, pp. 5473-5496. https://doi.org/10.1175/2007JCLI1824.1

Rio, M.H., Guinehut, S., Larnicol, G., 2011. New CNES-CLS09 global mean dynamic topography computed from the combination of GRACE data, altimetry, and in situ measurements. J. Geophys. Res. Oceans 116, p. C07018. https://doi.org/10.1029/2010JC006505

Rio, M.H., Poulain, P.M., Pascual, A., Mauri, E., Larnicol, G., Santoleri, R., 2007. A Mean Dynamic Topography of the Mediterranean Sea computed from altimetric data, in-situ measurements and a general circulation model. J. Marine Syst. 65, pp. 484-508.

https://doi.org/10.1016/j.jmarsys.2005.02.006 
Rivas, A.L., Pisoni, J.P., 2010. Identification, characteristics and seasonal evolution of surface thermal fronts in the Argentinean Continental Shelf. J. Marine Syst. 79, pp. 134-143.

https://doi.org/10.1016/j.jmarsys.2009.07.008

Robinson, A.R., Golnaraghi, M., 1994. The Physical and Dynamical Oceanography of the Mediterranean Sea, in: Malanotte-Rizzoli, P., Robinson, A.R. (Eds.), Ocean Processes in Climate Dynamics: Global and Mediterranean Examples, NATO ASI Series. Springer Netherlands, Dordrecht, pp. 255-306. https://doi.org/10.1007/978-94-011-0870-6_12

Robinson, A.R., Leslie, W.G., Theocharis, A., Lascaratos, A., 2001. Mediterranean Sea circulation. Encyclopedia of Ocean Sciences Academic Press, Harcourt Science \& Technology, Harcourt Place, 32 Jamestown Road London NW1 7BY UK, pp. 1689-1705. https://doi.org/10.1006/rwos.2001.0376

Roether, W., Klein, B., Manca, B.B., Theocharis, A., Kioroglou, S., 2007. Transient Eastern Mediterranean deep waters in response to the massive dense-water output of the Aegean Sea in the 1990s. Prog. Oceanogr. 74, pp. 540-571. https://doi.org/10.1016/j.pocean.2007.03.001

Ruiz, S., Pascual, A., Garau, B., Faugère, Y., Alvarez, A., Tintoré, J., 2009. Mesoscale dynamics of the Balearic Front, integrating glider, ship and satellite data. J. Marine Syst. 78, pp. S3-S16. https://doi.org/10.1016/j.jmarsys.2009.01.007

Salat J (1995). The interaction between the catalan and balearic currents in the southern catalan sea. Oceanologica Acta, 18(2), pp. 227-234. Open Access version :

https://archimer.ifremer.fr/doc/00096/20774/

Salgado-Hernanz, P.M., Racault, M.-F., Font-Muñoz, J.S., Basterretxea, G., 2019. Trends in phytoplankton phenology in the Mediterranean Sea based on ocean-colour remote sensing. Remote Sensing of Environment 221, 50-64. https://doi.org/10.1016/j.rse.2018.10.036

Saraceno, M., Provost, C., Piola, A.R., Bava, J., Gagliardini, A., 2004. Brazil Malvinas Frontal System as seen from 9 years of advanced very high resolution radiometer data. J. Geophys. Res. Oceans 109, p. C05027. https://doi.org/10.1029/2003JC002127

Schott, F., Visbeck, M., Send, U., Fischer, J., Stramma, L., Desaubies, Y., 1996. Observations of Deep Convection in the Gulf of Lions, Northern Mediterranean, during the Winter of 1991/92. J. Phys. Oceanogr. 26, pp. 505-524. https://doi.org/10.1175/15200485(1996)026\%3C0505:OODCIT\%3E2.0.CO;2

Schroeder, K., Haza, A.C., Griffa, A., Özgökmen, T.M., Poulain, P.M., Gerin, R., Peggion, G., Rixen, M., 2011. Relative dispersion in the Liguro-Provençal basin: From sub-mesoscale to mesoscale. Deep-Sea Res. Pt. I 58, pp. 209-228. https://doi.org/10.1016/j.dsr.2010.11.004

Schroeder, K., Josey, S.A., Herrmann, M., Grignon, L., Gasparini, G.P., Bryden, H.L., 2010. Abrupt warming and salting of the Western Mediterranean Deep Water after 2005: Atmospheric forcings and lateral advection. J. Geophys. Res. 115, p. C08029. https://doi.org/10.1029/2009JC005749

Schroeder, K., Taillandier, V., Vetrano, A., Gasparini, G.P., 2008. The circulation of the western Mediterranean Sea in spring 2005 as inferred from observations and from model outputs. Deep-Sea Res. Pt. I 55, pp. 947-965. https://doi.org/10.1016/j.dsr.2008.04.003

Seyfried, L., Estournel, C., Marsaleix, P., Richard, E., 2019. Dynamics of the North Balearic Front during an autumn tramontane and mistral storm: air-sea coupling processes and stratification budget diagnostic. Ocean Sci. 15, pp. 179-198. https://doi.org/10.5194/os-15-179-2019 
Seyfried, L., Marsaleix, P., Richard, E., Estournel, C., 2017. Modelling deep-water formation in the north-west Mediterranean Sea with a new air-sea coupled model: sensitivity to turbulent flux parameterizations. Ocean Sci. 13, pp. 1093-1112. https://doi.org/10.5194/os-13-1093-2017

Shaw, A.G.P., Vennell, R., 2000. A Front-Following Algorithm for AVHRR SST Imagery. Remote Sens. Environ. 72, pp. 317-327. https://doi.org/10.1016/S0034-4257(99)00108-X

Simpson, J.J., 1990. On the accurate detection and enhancement of oceanic features observed in satellite data. Remote Sens. Environ. 33, pp. 17-33. https://doi.org/10.1016/0034-4257(90)90052-N

Small, R.J., Carniel, S., Campbell, T., Teixeira, J., Allard, R., 2012. The response of the Ligurian and Tyrrhenian Seas to a summer Mistral event: A coupled atmosphere-ocean approach. Ocean Model. 48, pp. 30-44. https://doi.org/10.1016/j.ocemod.2012.02.003

Smith, R.O., Bryden, H.L. and Stansfield, K. (2008) Observations of new western Mediterranean deep water formation using Argo floats 2004-2006. Ocean Science, 4 (2), pp. 133-149 .https://ui.adsabs.harvard.edu/abs/2008OcSci...4..133S/abstract

Somot, S., Houpert, L., Sevault, F., Testor, P., Bosse, A., Taupier-Letage, I., Bouin, M.N., Waldman, R., Cassou, C., Sanchez-Gomez, E., Durrieu de Madron, X., Adloff, F., Nabat, P., Herrmann, M., 2018. Characterizing, modelling and understanding the climate variability of the deep water formation in the North-Western Mediterranean Sea. Clim Dyn 51, pp. 1179-1210. https://doi.org/10.1007/s00382-016-3295-0

Somot, S., Sevault, F., Déqué, M., Crépon, M., 2008. 21st century climate change scenario for the Mediterranean using a coupled atmosphere-ocean regional climate model. Global Planet. Change 63, pp. 112-126. https://doi.org/10.1016/j.gloplacha.2007.10.003

Soto-Navarro, J., Criado-Aldeanueva, F., García-Lafuente, J., Sánchez-Román, A., 2010. Estimation of the Atlantic inflow through the Strait of Gibraltar from climatological and in situ data. J. Geophys. Res. 115, p. C10023. https://doi.org/10.1029/2010JC006302

Spall, M.A., 1995. Frontogenesis, subduction, and cross-front exchange at upper ocean fronts. J. Geophys. Res. 100, p. 2543. https://doi.org/10.1029/94JC02860

Stanev, E., Friedrich, H.J., Botev, S., 1989. On the seasonal response of intermediate and deep water to surface forcing in the Mediterranean Sea. Oceanolog. Acta 11 (2), 141-149.

https://archimer.ifremer.fr/doc/00131/24225/

Stemmann, L., Gorsky, G., Marty, J.-C., Picheral, M., Miquel, J.-C., 2002. Four-year study of largeparticle vertical distribution $(0-1000 \mathrm{~m})$ in the NW Mediterranean in relation to hydrology, phytoplankton, and vertical flux. Deep Sea Research Part II: Topical Studies in Oceanography, Studies at the DYFAMED (France JGOFS) Time-Series Station, N.W. M editerranean Sea 49, 2143 2162. https://doi.org/10.1016/S0967-0645(02)00032-2

Stemmann, L., Prieur, L., Legendre, L., Taupier-Letage, I., Picheral, M., Guidi, L., Gorsky, G., 2008. Effects of frontal processes on marine aggregate dynamics and fluxes: An interannual study in a permanent geostrophic front (NW Mediterranean). J. Marine Syst. 70, pp. 1-20. https://doi.org/10.1016/j.jmarsys.2007.02.014

Stuhlmacher, A., Gade, M., 2020. Statistical analyses of eddies in the Western Mediterranean Sea based on Synthetic Aperture Radar imagery. Remote Sensing of Environment 250, 112023.

https://doi.org/10.1016/j.rse.2020.112023 
Testor, P., Béranger, K., Mortier, L., 2005a. Modeling the deep eddy field in the southwestern Mediterranean: The life cycle of Sardinian eddies. Geophys. Res. Lett. 32, p. L13602. https://doi.org/10.1029/2004GL022283

Testor, P., Bosse, A., Houpert, L., Margirier, F., Mortier, L., Legoff, H., Dausse, D., Labaste, M., Karstensen, J., Hayes, D., Olita, A., Ribotti, A., Schroeder, K., Chiggiato, J., Onken, R., Heslop, E., Mourre, B., D'Ortenzio, F., Mayot, N., Lavigne, H., de Fommervault, O., Coppola, L., Prieur, L., Taillandier, V., Durrieu de Madron, X., Bourrin, F., Many, G., Damien, P., Estournel, C., Marsaleix, P., Taupier-Letage, I., Raimbault, P., Waldman, R., Bouin, M.N., Giordani, H., Caniaux, G., Somot, S., Ducrocq, V., Conan, P., 2018. Multiscale Observations of Deep Convection in the Northwestern Mediterranean Sea During Winter 2012-2013 Using Multiple Platforms. J. Geophys. Res. Oceans 123, pp. 1745-1776. https://doi.org/10.1002/2016JC012671

Testor, P., de Young, B., Rudnick, D.L., Glenn, S., Hayes, D., Lee, C.M., Pattiaratchi, C., Hill, K., Heslop, E., Turpin, V., Alenius, P., Barrera, C., Barth, J.A., Beaird, N., Bécu, G., Bosse, A., Bourrin, F., Brearley, J.A., Chao, Y., Chen, S., Chiggiato, J., Coppola, L., Crout, R., Cummings, J., Curry, B., Curry, R., Davis, R., Desai, K., DiMarco, S., Edwards, C., Fielding, S., Fer, I., Frajka-Williams, E., Gildor, H., Goni, G., Gutierrez, D., Haugan, P., Hebert, D., Heiderich, J., Henson, S., Heywood, K., Hogan, P., Houpert, L., Huh, S., E. Inall, M., Ishii, M., Ito, S., Itoh, S., Jan, S., Kaiser, J., Karstensen, J., Kirkpatrick, B., Klymak, J., Kohut, J., Krahmann, G., Krug, M., McClatchie, S., Marin, F., Mauri, E., Mehra, A., P. Meredith, M., Meunier, T., Miles, T., Morell, J.M., Mortier, L., Nicholson, S., O’Callaghan, J., O'Conchubhair, D., Oke, P., Pallàs-Sanz, E., Palmer, M., Park, J., Perivoliotis, L., Poulain, P.M., Perry, R., Queste, B., Rainville, L., Rehm, E., Roughan, M., Rome, N., Ross, T., Ruiz, S., Saba, G., Schaeffer, A., Schönau, M., Schroeder, K., Shimizu, Y., Sloyan, B.M., Smeed, D., Snowden, D., Song, Y., Swart, S., Tenreiro, M., Thompson, A., Tintoré, J., Todd, R.E., Toro, C., Venables, H., Wagawa, T., Waterman, S., Watlington, R.A., Wilson, D., 2019. OceanGliders: A Component of the Integrated GOOS. Front. Mar. Sci. 6, p. 422.

https://doi.org/10.3389/fmars.2019.00422

Thibault, D., Gaudy, R., Le Fèvre, J., 1994. Zooplankton biomass, feeding and metabolism in a geostrophic frontal area (Almeria-Oran Front, western Mediterranean). Significance to pelagic food webs. Journal of Marine Systems, Processes and Fluxes in the Geostrophic Almeria-Oran Front 5, 297-311. https://doi.org/10.1016/0924-7963(94)90052-3

Tintoré, J., Pinardi, N., Álvarez-Fanjul, E., Aguiar, E., Álvarez-Berastegui, D., Bajo, M., Balbin, R., Bozzano, R., Nardelli, B.B., Cardin, V., Casas, B., Charcos-Llorens, M., Chiggiato, J., Clementi, E., Coppini, G., Coppola, L., Cossarini, G., Deidun, A., Deudero, S., D’Ortenzio, F., Drago, A., Drudi, M., El Serafy, G., Escudier, R., Farcy, P., Federico, I., Fernández, J.G., Ferrarin, C., Fossi, C., Frangoulis, C., Galgani, F., Gana, S., García Lafuente, J., Sotillo, M.G., Garreau, P., Gertman, I., Gómez-Pujol, L., Grandi, A., Hayes, D., Hernández-Lasheras, J., Herut, B., Heslop, E., Hilmi, K., Juza, M., Kallos, G., Korres, G., Lecci, R., Lazzari, P., Lorente, P., Liubartseva, S., Louanchi, F., Malacic, V., Mannarini, G., March, D., Marullo, S., Mauri, E., Meszaros, L., Mourre, B., Mortier, L., Muñoz-Mas, C., Novellino, A., Obaton, D., Orfila, A., Pascual, A., Pensieri, S., Pérez Gómez, B., Pérez Rubio, S., Perivoliotis, L., Petihakis, G., de la Villéon, L.P., Pistoia, J., Poulain, P.M., Pouliquen, S., Prieto, L., Raimbault, P., Reglero, P., Reyes, E., Rotllan, P., Ruiz, S., Ruiz, J., Ruiz, I., Ruiz-Orejón, L.F., Salihoglu, B., Salon, S., Sammartino, S., Sánchez Arcilla, A., Sánchez-Román, A., Sannino, G., Santoleri, R., Sardá, R., Schroeder, K., Simoncelli, S., Sofianos, S., Sylaios, G., Tanhua, T., Teruzzi, A., Testor, P., Tezcan, D., Torner, M., Trotta, F., Umgiesser, G., von Schuckmann, K., Verri, G., Vilibic, I., Yucel, M., Zavatarelli, M., Zodiatis, G., 2019. Challenges for Sustained Observing and Forecasting Systems in the Mediterranean Sea. Front. Mar. Sci. 6, p. 568. https://doi.org/10.3389/fmars.2019.00568

Turiel, A., Solé, J., Nieves, V., Ballabrera-Poy, J., García-Ladona, E., 2008. Tracking oceanic currents by singularity analysis of Microwave Sea Surface Temperature images. Remote Sens. Environ., Earth 
Observations for Terrestrial Biodiversity and Ecosystems Special Issue 112, pp. 2246-2260. https://doi.org/10.1016/j.rse.2007.10.007

Turner, J.S., 1980. Buoyancy Effects in Fluids. Cambridge University Press, Cambridge, UK.

Uitz, J., Stramski, D., Gentili, B., D’Ortenzio, F., Claustre, H., 2012. Estimates of phytoplankton class-specific and total primary production in the Mediterranean Sea from satellite ocean color observations. Global Biogeochem. Cycles 26. https://doi.org/10.1029/2011GB004055

Ullman, D.S., Cornillon, P.C., 2000. Evaluation of Front Detection Methods for Satellite-Derived SST Data Using In Situ Observations. J. Atmos. Oceanic Technol. 17, pp. 1667-1675. https://doi.org/10.1175/1520-0426(2000)017\%3C1667:EOFDMF\%3E2.0.CO;2

Vargas-Yáñez, M., Jesús García, M., Salat, J., García-Martínez, M.C., Pascual, J., Moya, F., 2008. Warming trends and decadal variability in the Western Mediterranean shelf. Global Planet. Change 63, pp. 177-184. https://doi.org/10.1016/j.gloplacha.2007.09.001

Vargas-Yáñez, M., Juza, M., Balbín, R., Velez-Belchí, P., García-Martínez, M.C., Moya, F., Hernández-Guerra, A., 2020. Climatological Hydrographic Properties and Water Mass Transports in the Balearic Channels From Repeated Observations Over 1996-2019. Front. Mar. Sci. 7, 568602. https://doi.org/10.3389/fmars.2020.568602

von Schuckmann, K., Le Traon, P.Y., Smith, N., Pascual, A., Djavidnia, S., Gattuso, J.P., Grégoire, M., Nolan, G., Aaboe, S., Aguiar, E., Álvarez Fanjul, E., Alvera-Azcárate, A., Aouf, L., Barciela, R., Behrens, A., Belmonte Rivas, M., Ben Ismail, S., Bentamy, A., Borgini, M., Brando, V.E., Bensoussan, N., Blauw, A., Bryère, P., Buongiorno Nardelli, B., Caballero, A., Çağlar Yumruktepe, V., Cebrian, E., Chiggiato, J., Clementi, E., Corgnati, L., de Alfonso, M., de Pascual Collar, Á., Deshayes, J., Di Lorenzo, E., Dominici, J.M., Dupouy, C., Drévillon, M., Echevin, V., Eleveld, M., Enserink, L., García Sotillo, M., Garnesson, P., Garrabou, J., Garric, G., Gasparin, F., Gayer, G., Gohin, F., Grandi, A., Griffa, A., Gourrion, J., Hendricks, S., Heuzé, C., Holland, E., Iovino, D., Juza, M., Kurt Kersting, D., Kipson, S., Kizilkaya, Z., Korres, G., Kõuts, M., Lagemaa, P., Lavergne, T., Lavigne, H., Ledoux, J.B., Legeais, J.F., Lehodey, P., Linares, C., Liu, Y., Mader, J., Maljutenko, I., Mangin, A., Manso-Narvarte, I., Mantovani, C., Markager, S., Mason, E., Mignot, A., Menna, M., Monier, M., Mourre, B., Müller, M., Nielsen, J.W., Notarstefano, G., Ocaña, O., Pascual, A., Patti, B., Payne, M.R., Peirache, M., Pardo, S., Pérez Gómez, B., Pisano, A., Perruche, C., Peterson, K.A., Pujol, M.I., Raudsepp, U., Ravdas, M., Raj, R.P., Renshaw, R., Reyes, E., Ricker, R., Rubio, A., Sammartino, M., Santoleri, R., Sathyendranath, S., Schroeder, K., She, J., Sparnocchia, S., Staneva, J., Stoffelen, A., Szekely, T., Tilstone, G.H., Tinker, J., Tintoré, J., Tranchant, B., Uiboupin, R., Van der Zande, D., von Schuckmann, K., Wood, R., Woge Nielsen, J., Zabala, M., Zacharioudaki, A., Zuberer, F., Zuo, H., 2019. Copernicus Marine Service Ocean State Report, Issue 3. J. Oper. Oceanogr. 12, pp. S1-S123. https://doi.org/10.1080/1755876X.2019.1633075

Waldman, R., Brüggemann, N., Bosse, A., Spall, M., Somot, S., Sevault, F., 2018. Overturning the Mediterranean Thermohaline Circulation. Geophys. Res. Lett. 45, pp. 8407-8415.

https://doi.org/10.1029/2018GL078502

Waldman, R., Herrmann, M., Somot, S., Arsouze, T., Benshila, R., Bosse, A., Chanut, J., Giordani, H., Sevault, F., Testor, P., 2017a. Impact of the Mesoscale Dynamics on Ocean Deep Convection: The 2012-2013 Case Study in the Northwestern Mediterranean Sea. J. Geophys. Res. Oceans 122, pp. 8813-8840. https://doi.org/10.1002/2016JC012587

Waldman, R., Somot, S., Herrmann, M., Bosse, A., Caniaux, G., Estournel, C., Houpert, L., Prieur, L., Sevault, F., Testor, P., 2017b. Modeling the intense 2012-2013 dense water formation event in the northwestern Mediterranean Sea: Evaluation with an ensemble simulation approach. J. Geophys. Res. Oceans 122, pp. 1297-1324. https://doi.org/10.1002/2016JC012437 
Yelekçi, Ö., Charria, G., Capet, X., Reverdin, G., Sudre, J., Yahia, H., 2017. Spatial and seasonal distributions of frontal activity over the French continental shelf in the Bay of Biscay. Cont. Shelf Res. 144, pp. 65-79. https://doi.org/10.1016/j.csr.2017.06.015

Zakardjian, B., Prieur, L., 1998. Biological and chemical signs of upward motions in permanent geostrophic fronts of the western Mediterranean. J. Geophys. Res. 103, pp. 27849-27866. https://doi.org/10.1029/98JC01537

Fig. 1. Overview of the main surface circulatory features and frontal structures in the studied area : $\mathrm{AC}, \mathrm{BC}, \mathrm{NC}$, and WCC respectively denote the Algerian Current, the Balearic Current, the Northern Current, and the West Corsica Current; circular arrows denote the Algerian Eddies (AEs) and Sardinian Eddies (SEs); DWF stands for Deep Water Formation; black arrows show the typical paths taken by the AEs; approximate locations of the main frontal structures are shown using red dashed lines for the Pyrenees Front (PF) and Balearic Front (BF) while the North Balearic Front (NBF) is indicated with a black dashed line; white and grey lines shows the paths of the two gliders used in Section 3.2 (respectively, CAMPE/MistralsT02_00 in fall 2012 and MILOU/ASICSMED in winter 2013); Tln, Mrs, Bnl, and Bfc show the locations of Toulon, Marseille, Banyuls-sur-mer, and Bonifacio.

Fig. 2. Climatology (20-year average) of surface fields and vertical distributions of temperature (a-b) and salinity (d-e) over the Western Mediterranean Basin as simulated in the reanalysis and used to compute the corresponding regional north-south gradients (panels $\mathrm{c}$ and $\mathrm{f}$ ); the black rectangle delineates the domain on which spatial averages are computed. Note that the vertical scale has been exaggerated in the upper $200 \mathrm{~m}$ on the center and right panels.

Fig. 3. Wind speeds from MEDRYS forcing (a, e, i, m, vectors are not to scale), SST and corresponding scaled gradients from the model reanalysis $(b, f, j, n)$ and remotely sensed SST HR, (c, $\mathrm{g}, \mathrm{k}, \mathrm{o}$ ) and VHR data (h, l, p). Grey and black contours identify the location of fronts based on gradients that exceed the climatological gradient by factors of five and ten, respectively. For clarity, the 5 isolines of scaled gradients were removed from the panels showing the remotely sensed $1 \mathrm{~km}$ SST for October 2012 and July 2008 (h, 1).

Fig. 4. Daily surface salinity and corresponding scaled gradients from the reanalysis $(a, d, g, j)$ and sea level and geostrophic velocity derived from the reanalysis $(b, e, f, k)$ and from altimetry $(c, f, i, l)$ for the same dates as in Fig. 3. Grey and black contours on salinity panels identify the location of fronts based on gradients that exceed the climatological gradient by factors of five and ten, respectively.

Fig. 5. Surface values (a-b) and corresponding vertical sections of temperature (left panels) and salinity (right panels) during the fall 2012 glider deployment (CAMPE/MistralT02_00, c-d) and as extracted from the reanalysis (e-f); glider data in black and reanalysis results in red on panels a-b; green lines on upper panels mark the day displayed in Figs. 3 and 4. See Fig. 1 for the glider path. Fig. 6. Same as Fig. 5 for the glider MILOU/ASICSMED in winter 2013 (January 24 to April 14).

Fig. 7. Long-term and seasonal averages of frontal occurrence (FO), based on reanalyzed surface salinity (a-e) and temperature (f-j), and remote sensing SST (k-o) . Black contours show FOs of (a) $30 \%, 40 \%$, and $50 \%$, (f) $20 \%$ and $30 \%$, (k) $5 \%$ and $25 \%$, (b-e) $30 \%$ and $50 \%$, (g-j) $30 \%$ and $45 \%$, (lo) $5 \%$ and $25 \%$. Long-term averages are computed from the 20-year reanalysis data (June 1993 to June 2013). 
Fig. 8. Five-year averages (Jan-2008 to Jun-2013) of SST FOs for the reanalysis (a) and remotely sensed HR (c) and VHR SST (b). Black lines represent FO isolines of (a) 15\% and 26\%, (b) 17\% and $24 \%$, and (c) $3 \%$ and $10 \%$.

Fig. 9. EOFs of (a) SST and (c) SSS frontal indices; (b, d) the corresponding temporal amplitudes of the principal components (PC). Black contours in (a) and (c) show the 0.01 isolines. Overlaid red curves are smoothed six-month averages of the PCs (blue).

Fig. 10. Yearly averaged (01-Jan to 31-Dec) SST frontal occurrences in the reanalysis data. Black contours correspond to the $10 \%$ and $25 \%$ isolines.

Fig. 11. As in Fig. 10 but for SSS. Black contours show the 30\% and $45 \%$ isolines.

Fig. 12. 20-year climatological fields (June 1993 to June 2013) of the reanalysed SSH (a) with SST(white, FO higher than 25\%, from Fig. 7) and SSS-based FO contours (black, FO higher than $30 \%$, from Fig. 7) and Summer (July to September) fields (b) of the reanalysed SSH with FO contours based on subsurface temperature $(30 \mathrm{~m}, 50 \%$, white) and SSS (30\%, black).

Fig. 13. Comparison of two winter events of the haline front position with (March 10, 2005, b-f) and without DWF (March 10, 2008, a-c) in the GoL: Surface salinity fields (lower panels), vertical sections along $5.3^{\circ} \mathrm{E}$ (middle panels) and corresponding normalized gradients of surface salinity. Normalized gradients superior to five and ten are highlighted with blue and red, respectively, on bottom and upper panels. Black contouring on surface salinity maps and vertical sections stands for the 37.8 isohaline.

Fig. 14. Time series of daily extent of the northwestern convection zone (green lines, right axis), meridional distribution of surface geostrophic EKE (a, logarithmic scale in $\mathrm{cm}^{2} . \mathrm{s}^{-2}$ ), 37.8 and 38.0 surface salinity isohalines (black and grey lines) and normalized SSS gradients (b). Salinity isohalines, $\log (\mathrm{EKE})$ and normalized gradient were averaged between $5-7^{\circ} \mathrm{E}$ and low-pass filtered with a 365-day window size. 


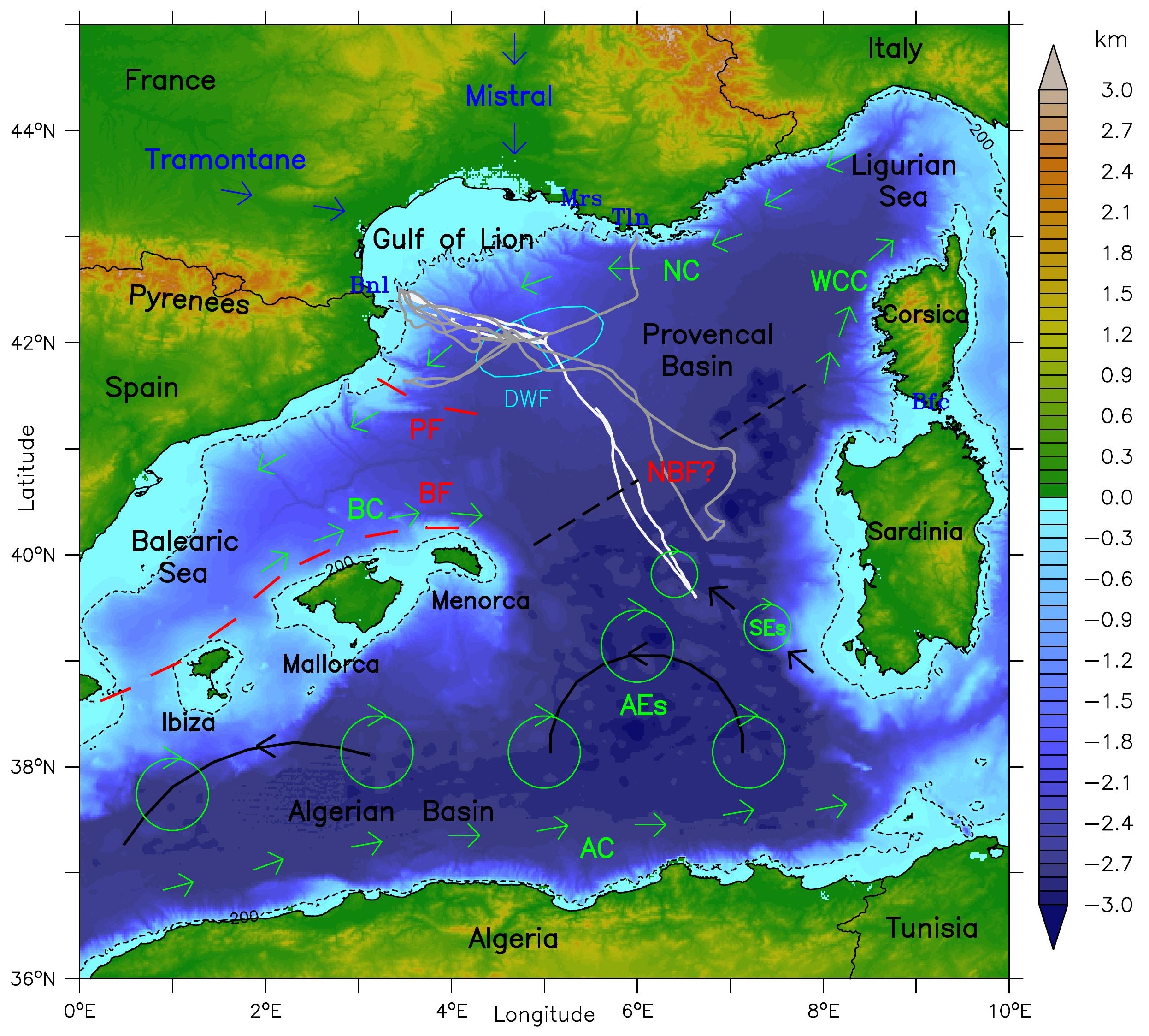




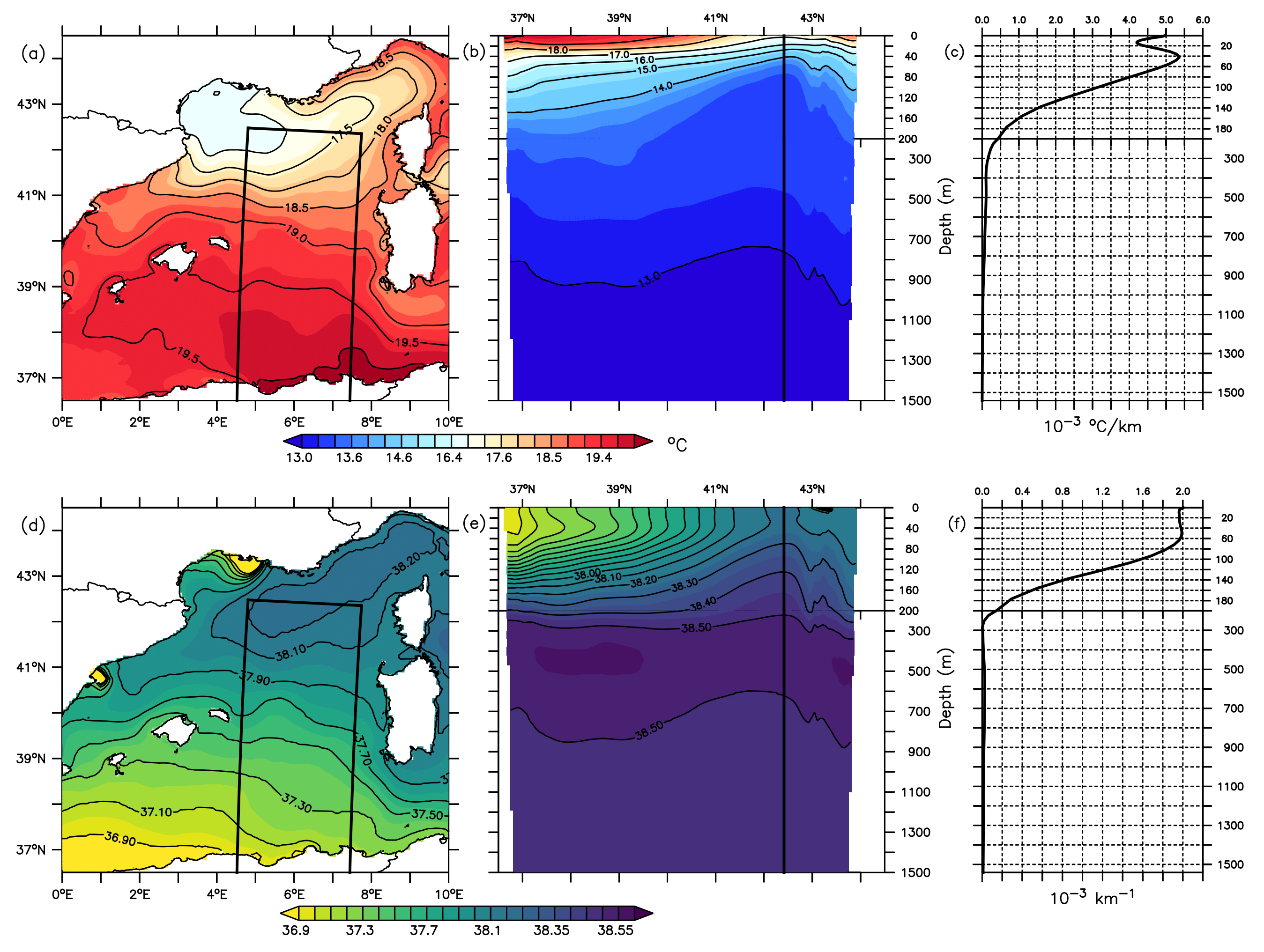




\section{ALDERA wind speed \\ MEDRYS-7km SST \\ CMEMS $-5 \mathrm{~km}$ SST \\ CMEMS-1km SST}

$\begin{array}{llllllllllllllllllllllll}0^{\circ} \mathrm{E} & 2^{\circ} \mathrm{E} & 4^{\circ} \mathrm{E} & 6^{\circ} \mathrm{E} & 8^{\circ} \mathrm{E} & 1^{\circ} \mathrm{E} & 0^{\circ} \mathrm{E} & 2^{\circ} \mathrm{E} & 4^{\circ} \mathrm{E} & 6^{\circ} \mathrm{E} & 8^{\circ} \mathrm{E} & 1^{\circ} \mathrm{E} & 0^{\circ} \mathrm{E} & 2^{\circ} \mathrm{E} & 4^{\circ} \mathrm{E} & 6^{\circ} \mathrm{E} & 8^{\circ} \mathrm{E} & 1^{\circ} \mathrm{E} & 0^{\circ} \mathrm{E} & 2^{\circ} \mathrm{E} & 4^{\circ} \mathrm{E} & 6^{\circ} \mathrm{E} & 8^{\circ} \mathrm{E} & 1^{\circ} \mathrm{E}\end{array}$

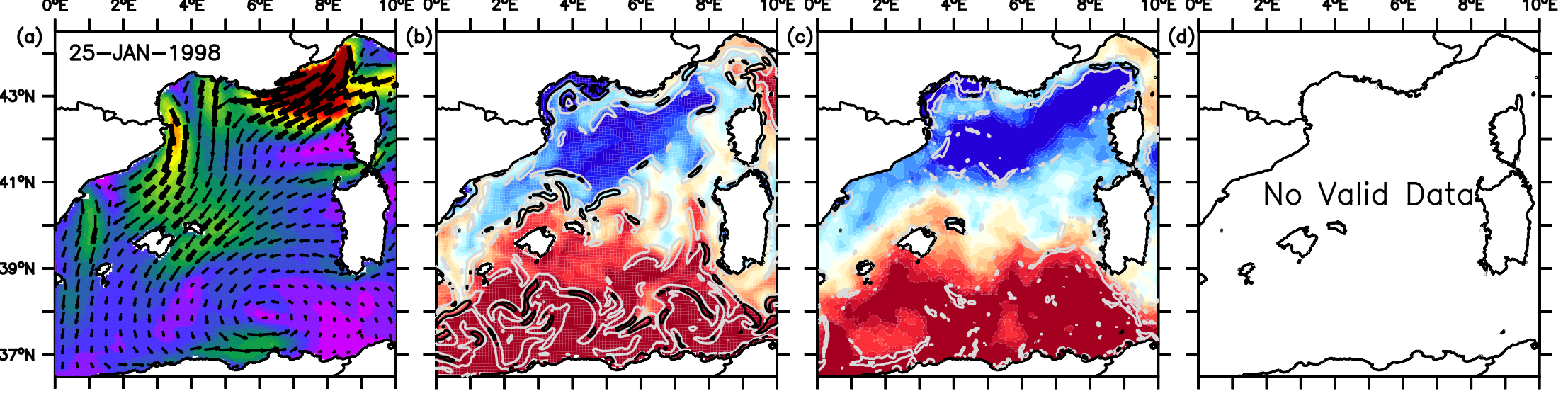

15.0
14.6
14.2
13.8
13.4
13.0
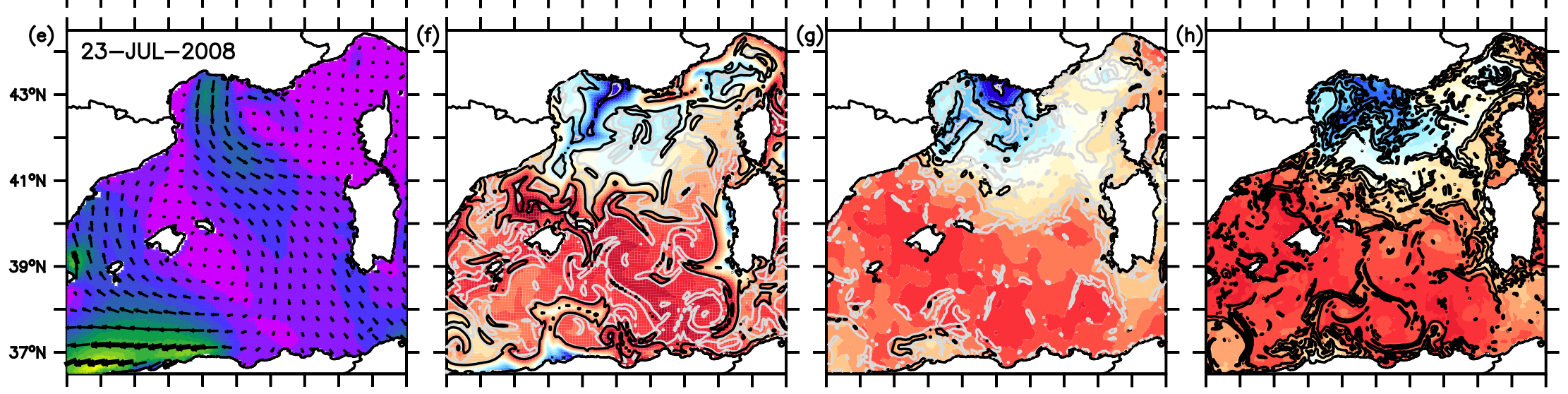

${ }^{\circ} \mathrm{C}$

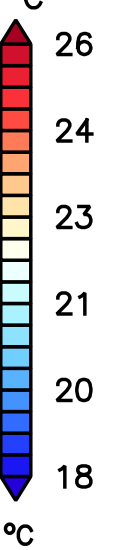

\section{.}

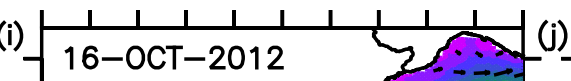
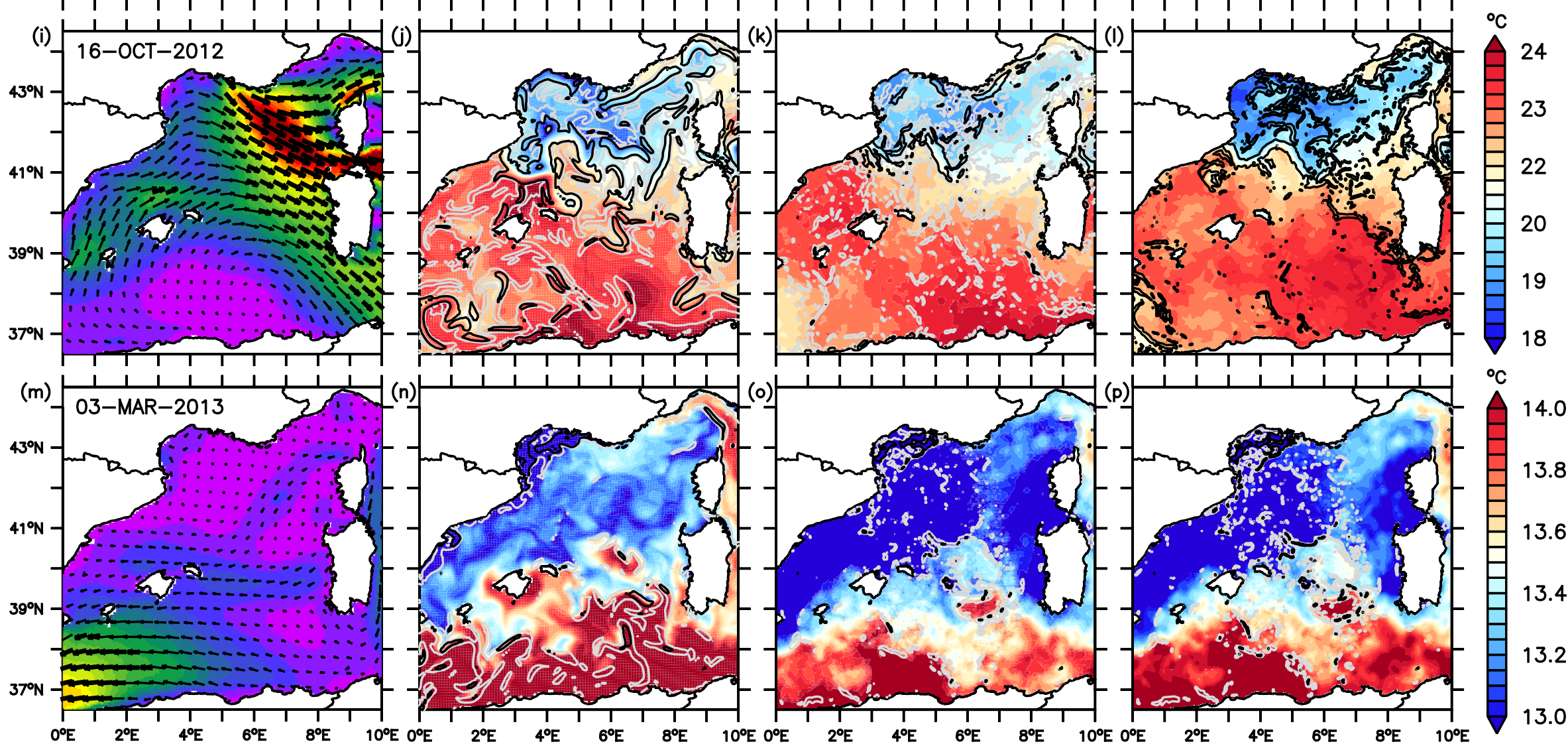

$\begin{array}{llllll}0 & 5 & 10 & 15 & 20 & 25\end{array}$ 


\section{MEDRYS SSS}

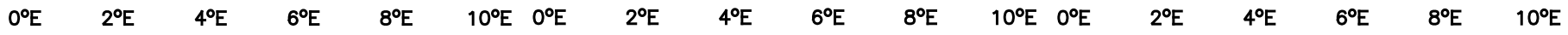
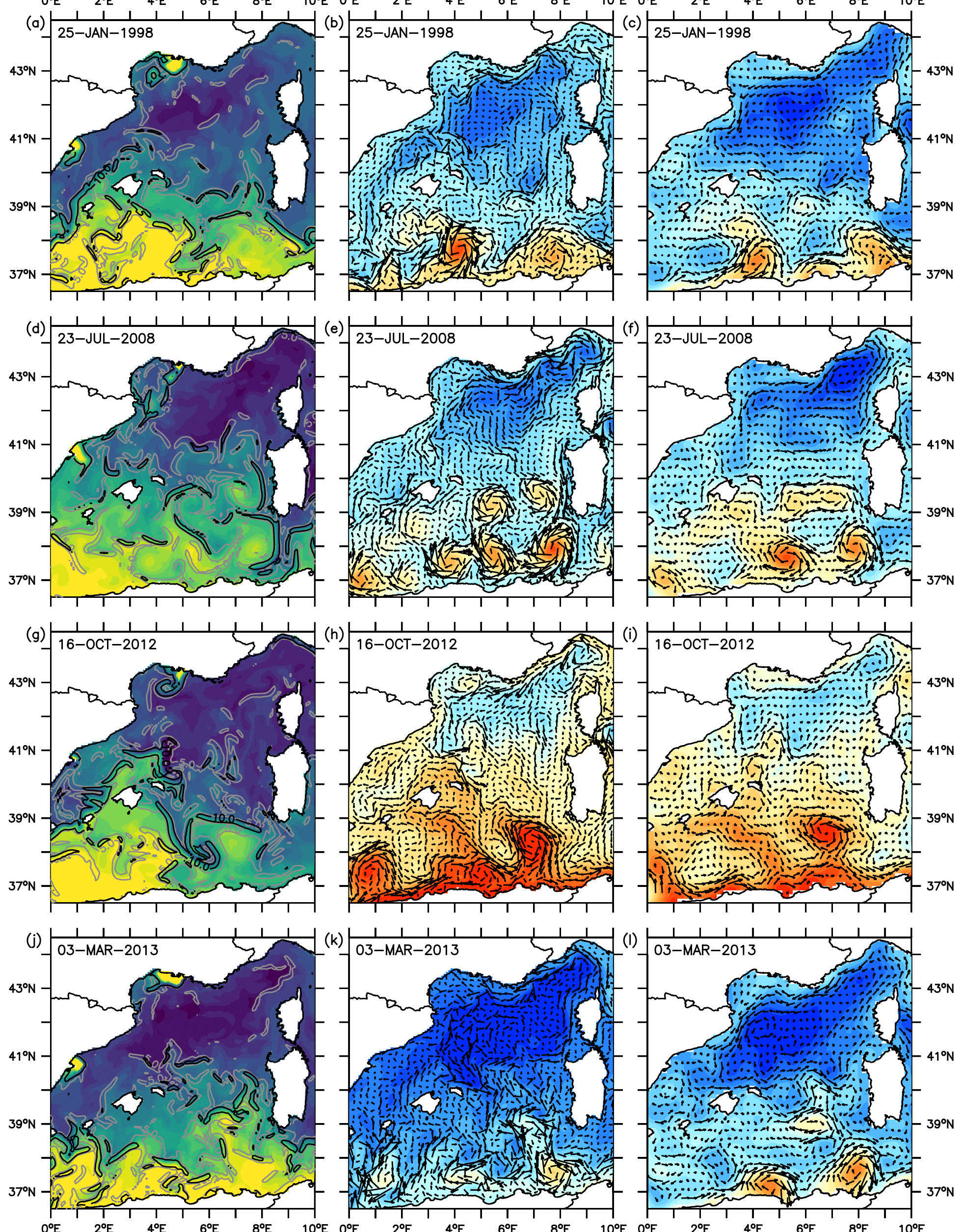

$\begin{array}{lllll}37.0 & 37.4 & 37.8 & 38.1 \quad 38.5\end{array}$ 

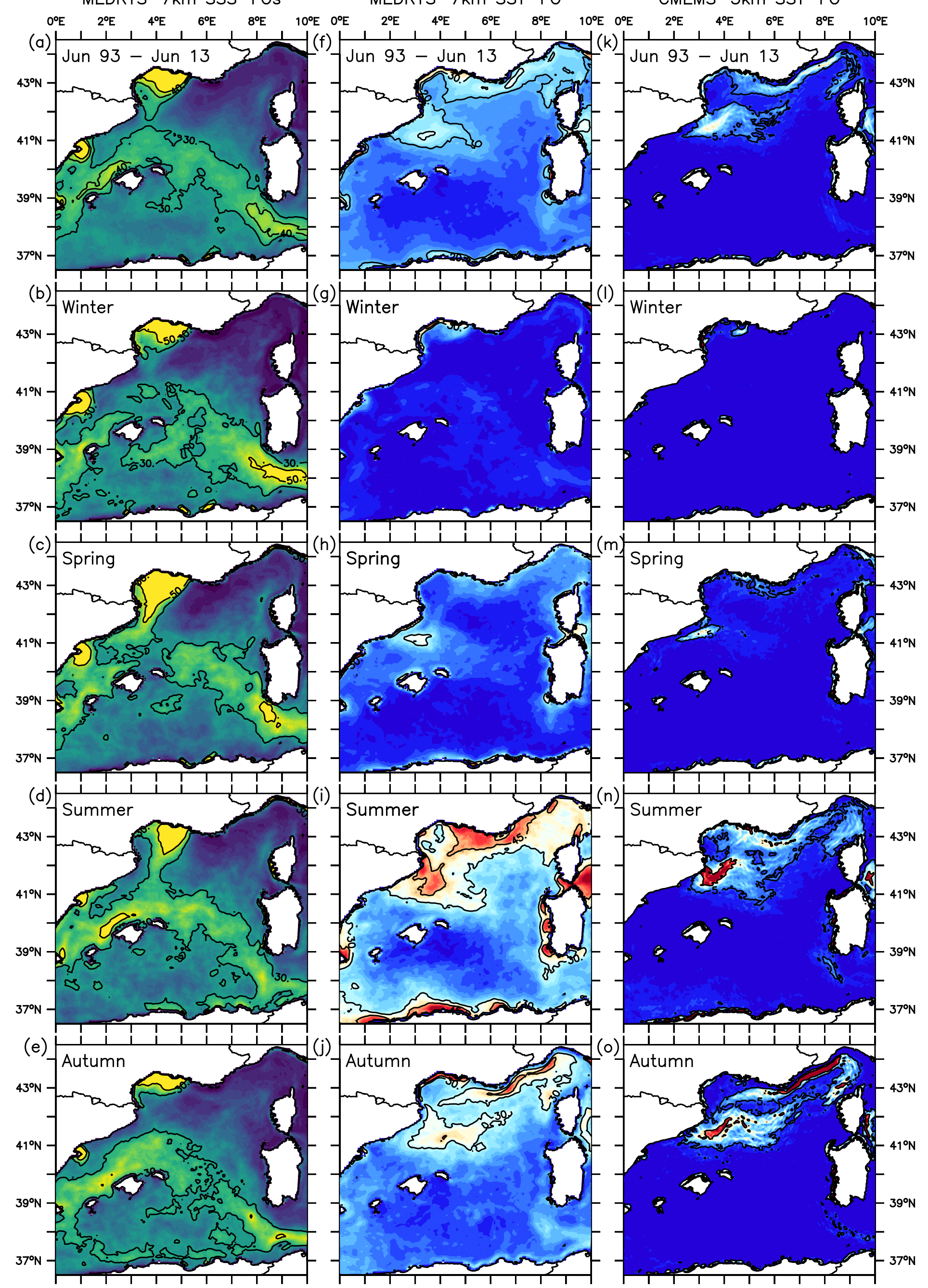

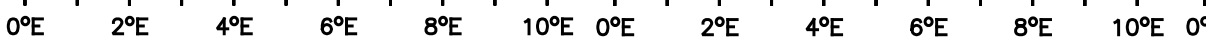

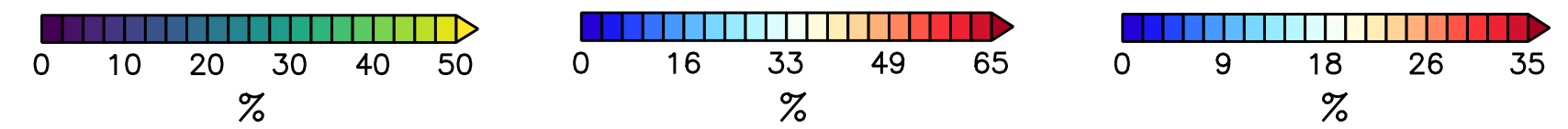




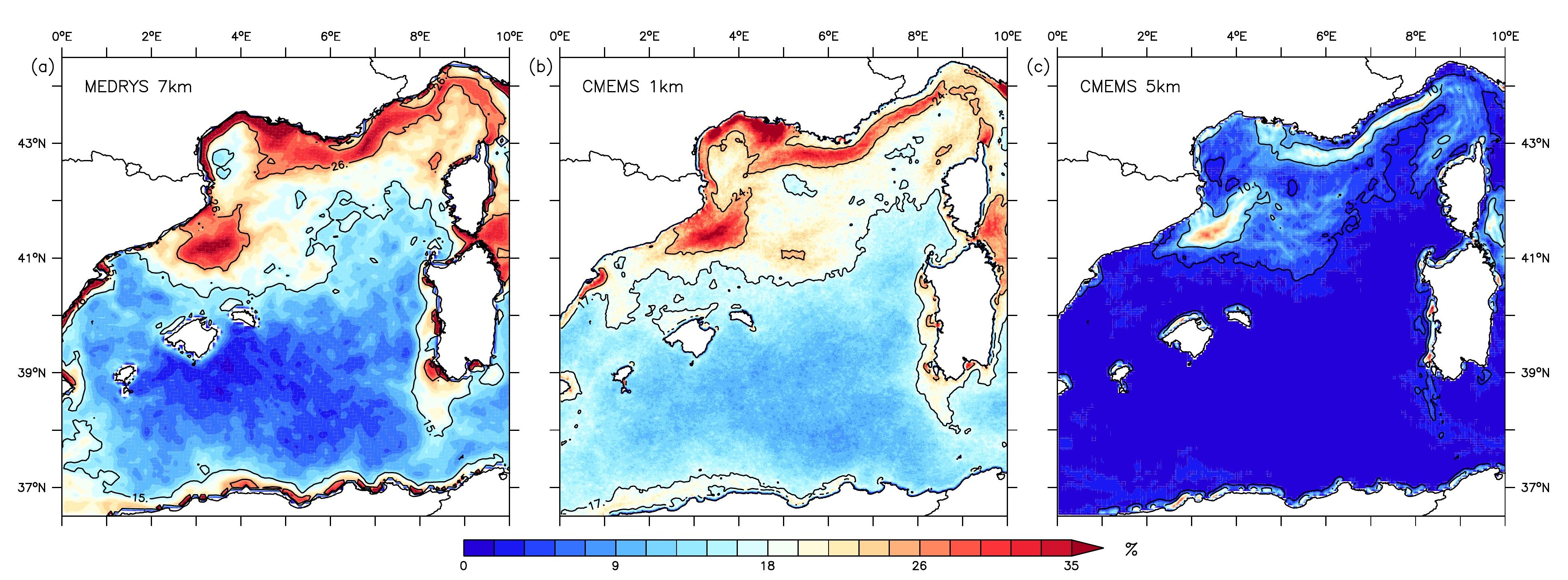




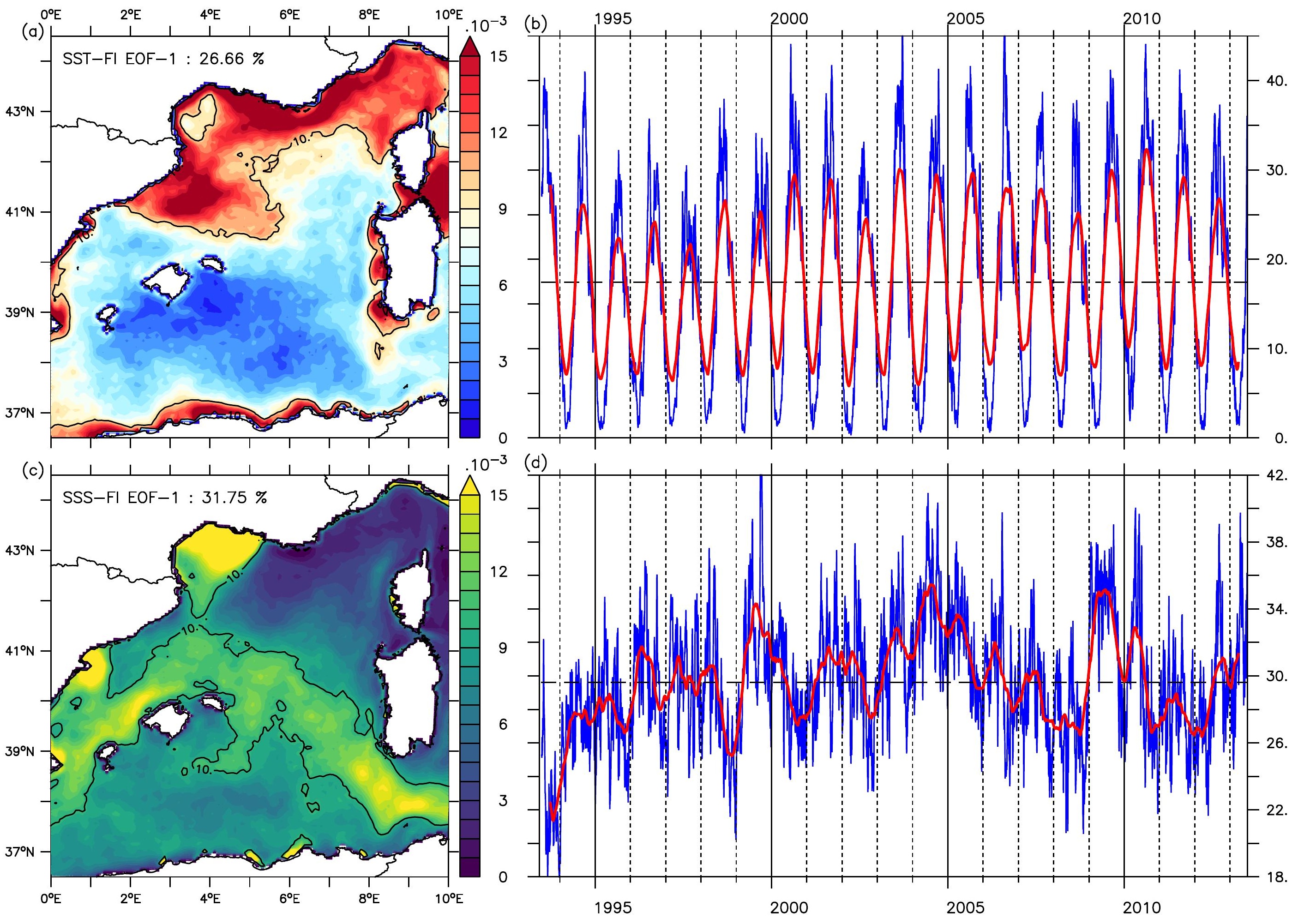




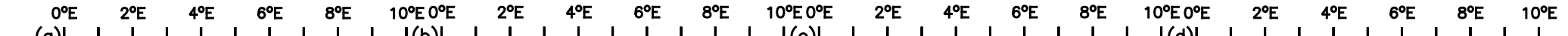
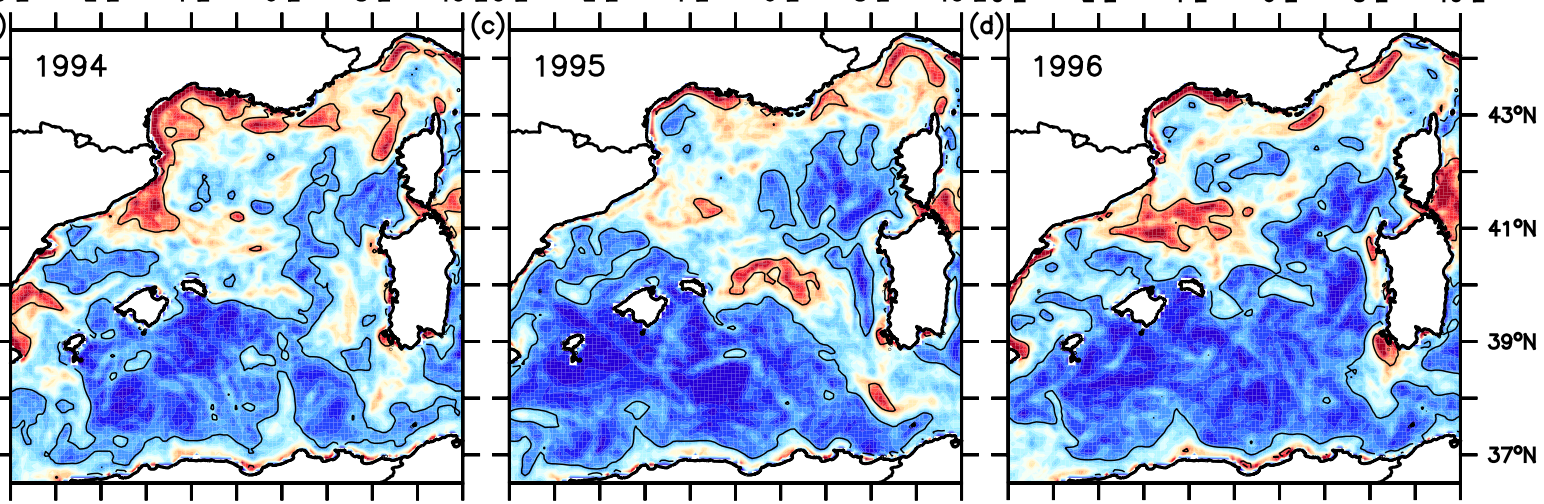

(e)

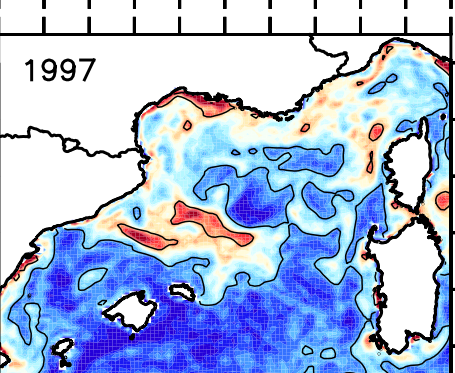

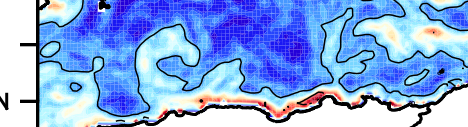
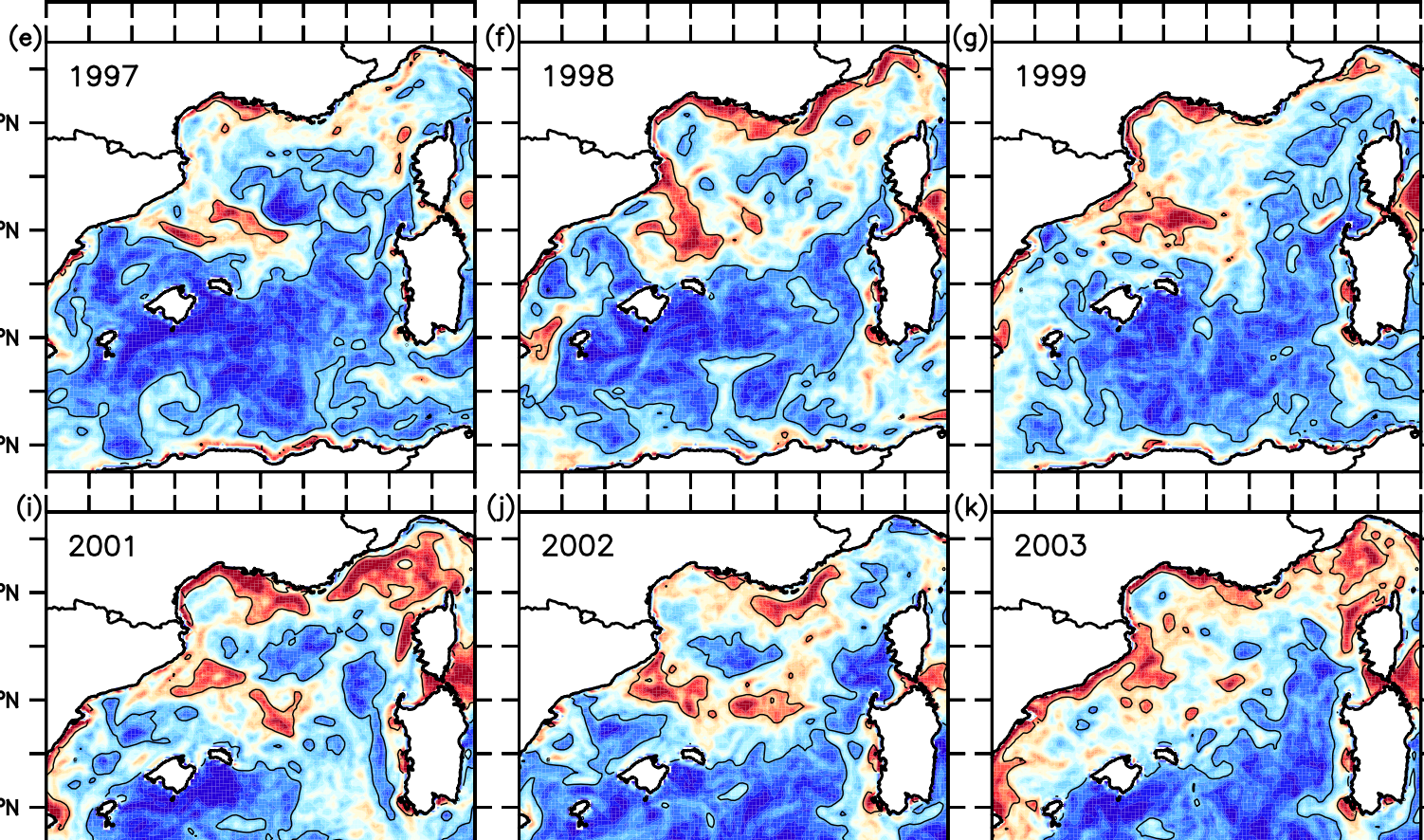

$\left.\{2\} 2 m{ }^{2}\right\}$
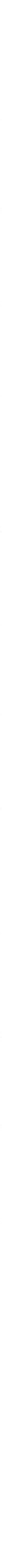

$37^{\circ} \mathrm{N}$ - 800 on

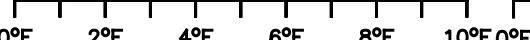
- Pon

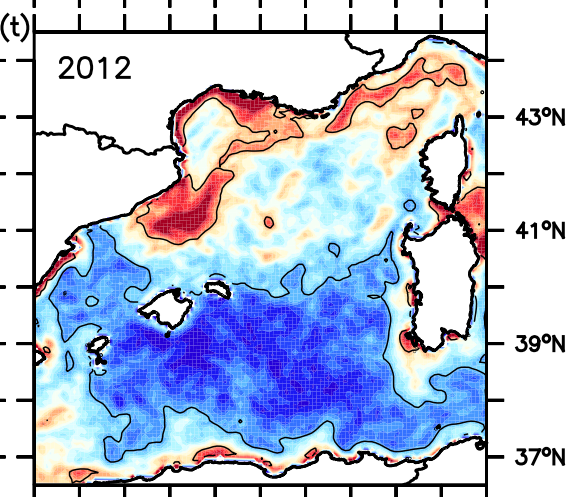

$\begin{array}{lllllllllll}0.0 & 3.5 & 7.0 & 10.5 & 14.0 & 17.5 & 21.0 & 24.5 & 28.0 & 31.5 & 35.0\end{array}$




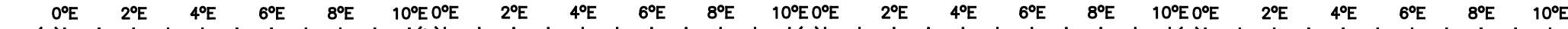

\section{(a)}

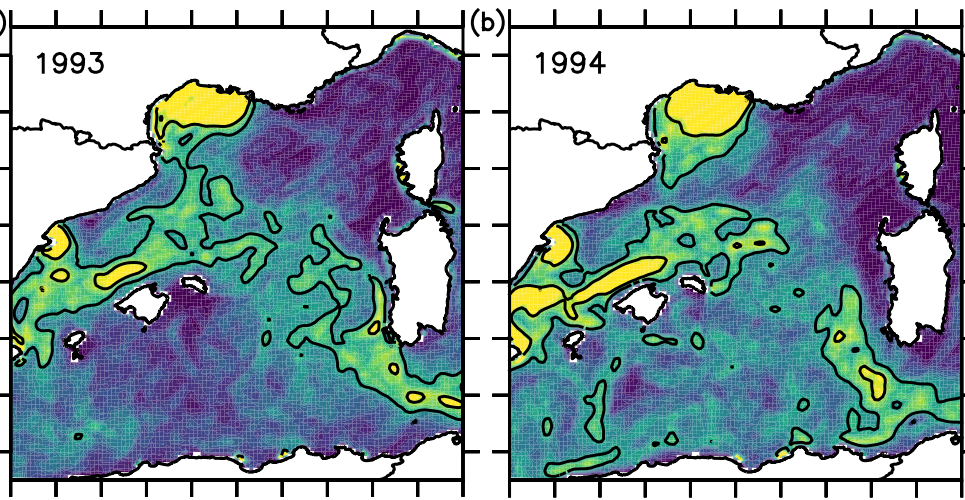

(e)
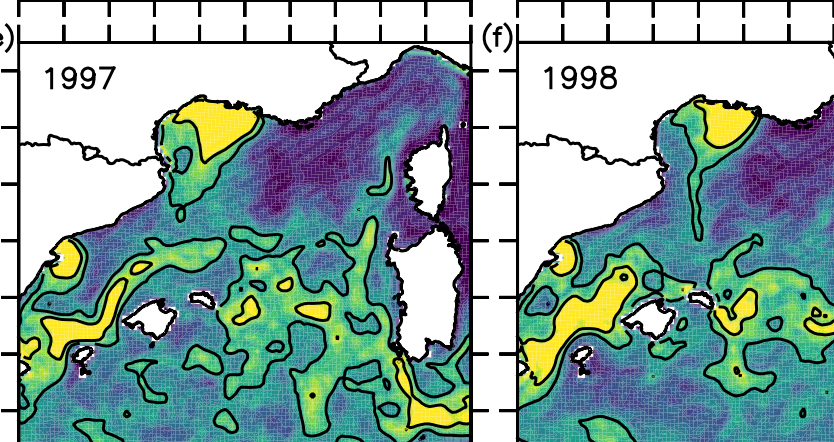

(g)
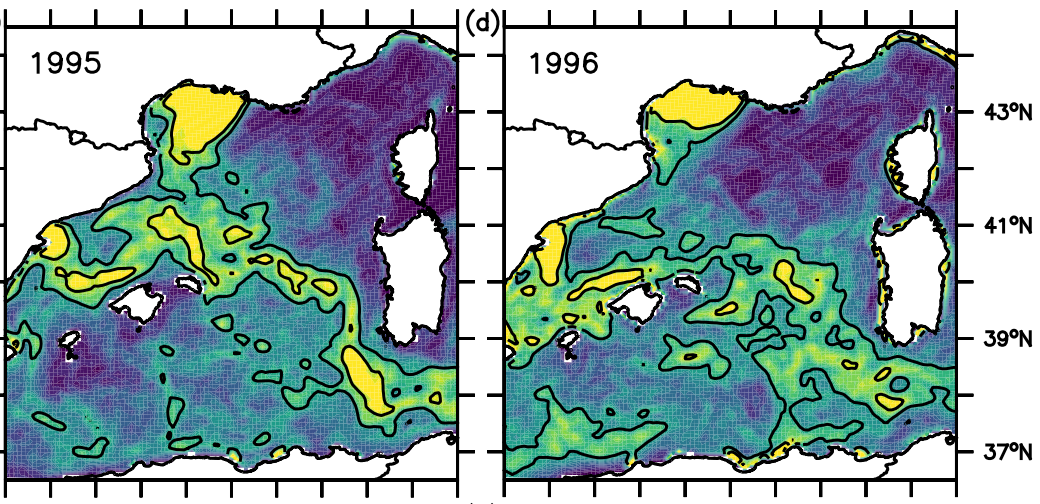

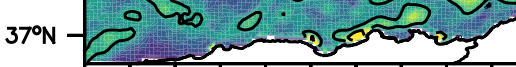
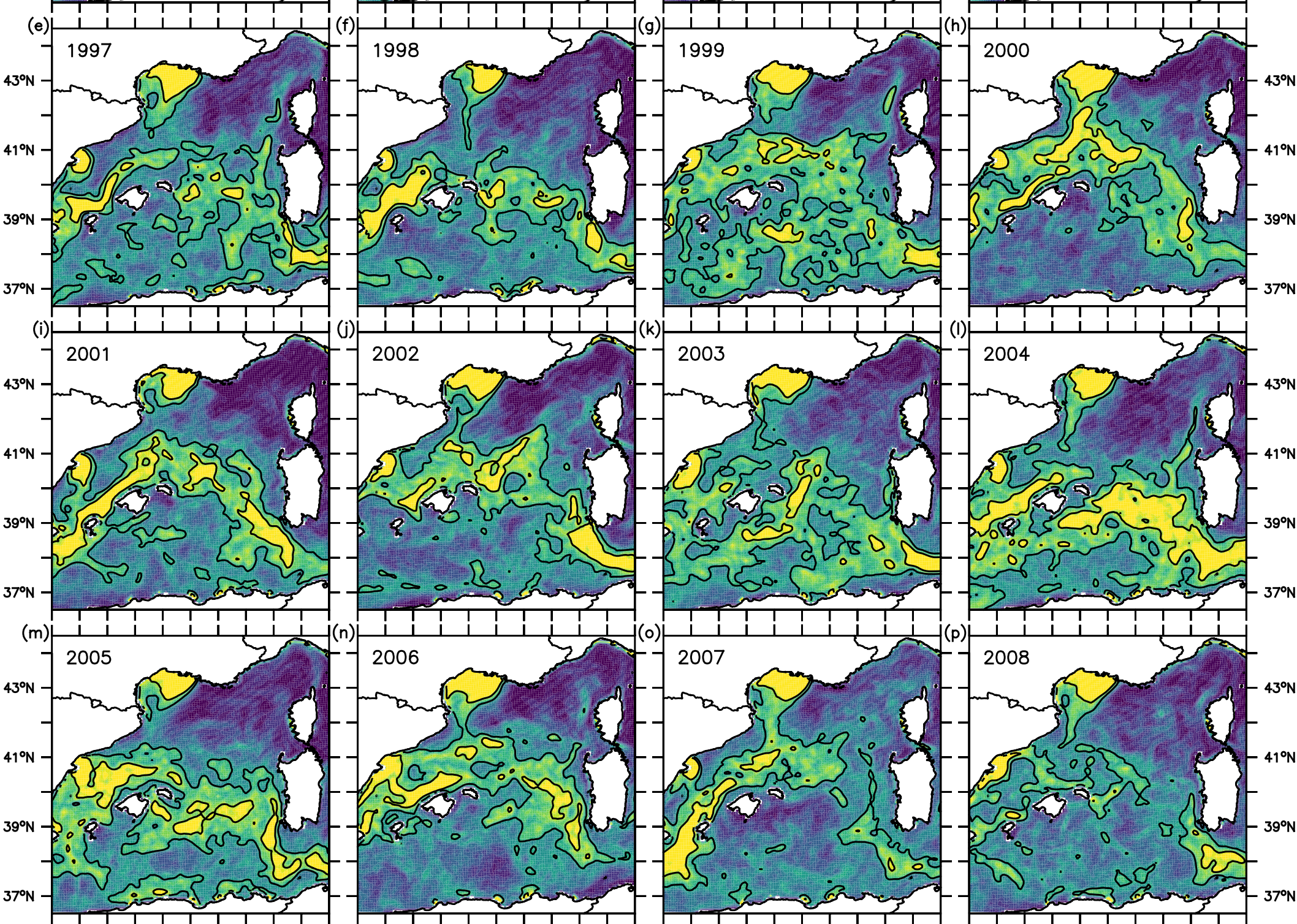

(a)

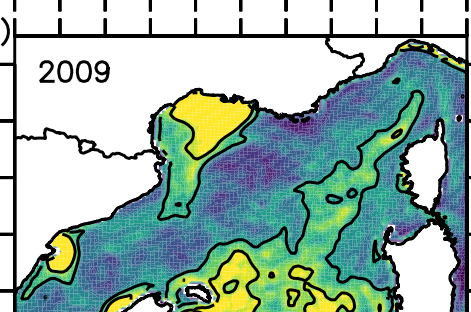
$30^{\circ} \mathrm{Non}$ $-15000$

$$
\text { of }
$$

$0^{\circ} \mathrm{E} 2^{\circ} \mathrm{E} \quad 4^{\circ} \mathrm{E} 6^{\circ} \mathrm{E} \quad 8^{\circ} \mathrm{E}$
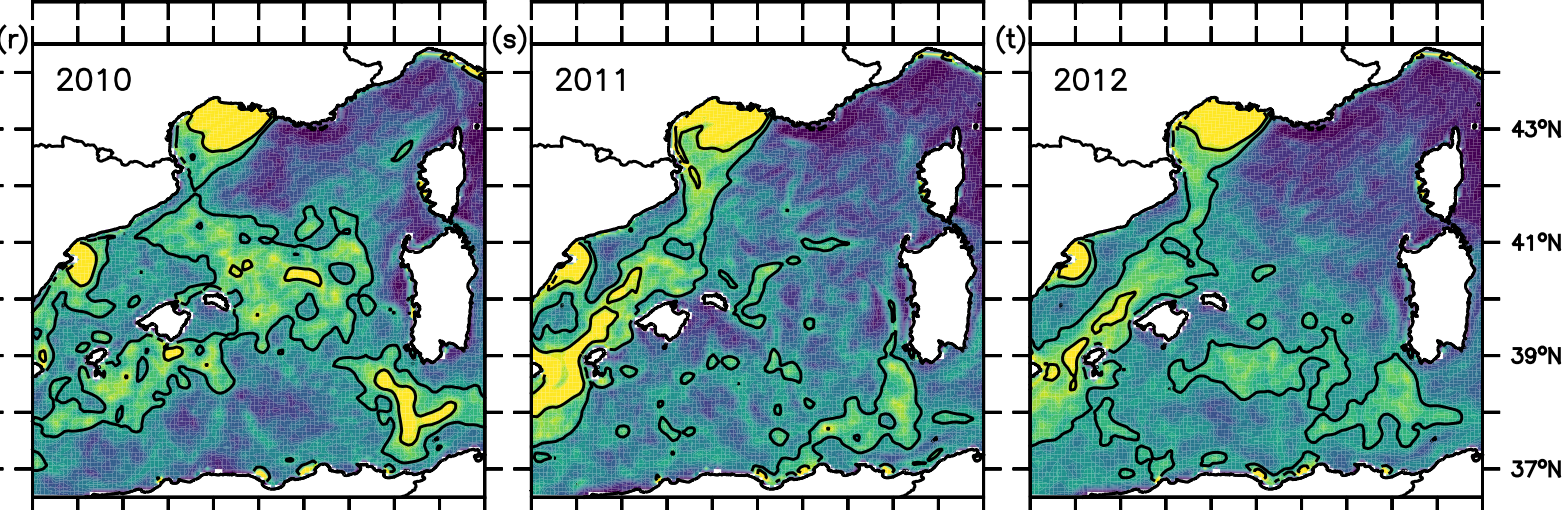

Q2

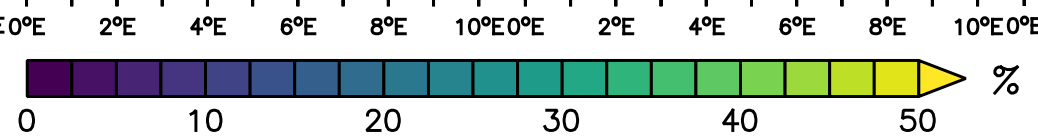




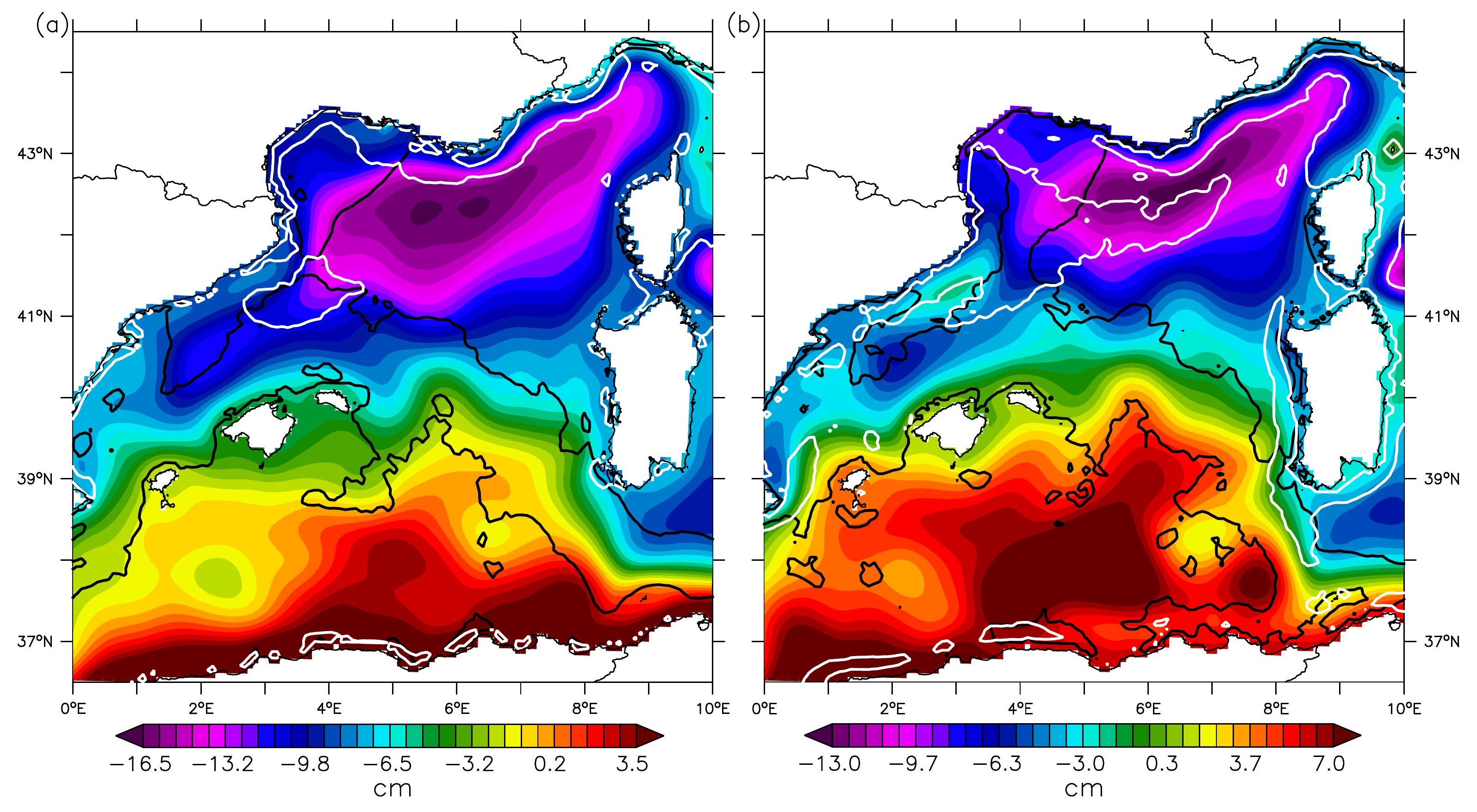



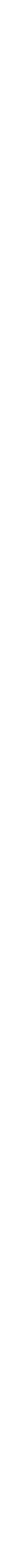